Grzegorz Chajko

Uniwersytet Papieski Jana Pawła II w Krakowie

\title{
Pałac arcybiskupów lwowskich obrządku łacińskiego w Obroszynie koło Lwowa w latach 1885-1923. Edycja źródłowa inwentarzy
}

W strukturze Kresów Południowo-Wschodnich Polski przedrozbiorowej, a także okresu międzywojennego, ważne miejsce zajmowały zamki, pałace i inne rezydencje szlacheckie rozsiane po całym Podolu, Wołyniu, Ziemi Czerwieńskiej i innych sąsiednich regionach. Wokół nich skupiało się życie nie tylko samej arystokracji i inteligencji, ale również szerszych środowisk polskich, które - obok świątyń rzymskokatolickich - niejednokrotnie uważało rezydencje za czynnik jednoczący skupiska polskie i traktowało je też jako miejsce pracy. W utrzymaniu obiektów, otaczających je ogrodów oraz w wielkopowierzchniowej gospodarce rolnej zatrudnienie znajdowała również okoliczna ludność.

Podobne zadania spełniały nieliczne rezydencje biskupie. Archidiecezja lwowska - jednostka kościelna odgrywająca niejednokrotnie w dziejach narodu polskiego rolę przedmurza chrześcijaństwa, dysponowała takimi w Dunajowie ${ }^{1}$ i w Obroszynie ${ }^{2}$ oraz w samym Lwowie. Niestety, ich dzieje, urządzenie wnętrz i kaplic oraz najważniejsze wydarzenia im towarzyszące zniknęły w mroku dziejów, czekając nadal na swoje odkrycie.

Niniejszy artykuł w pewnym stopniu uzupełnia istniejącą lukę w nieznanej historii pałacu arcybiskupów lwowskich w Obroszynie, położonym

1. Dunajów - miasteczko w pow. Przemyślany, woj. tarnopolskie.

2. Obroszyn - wieś w pow. Gródek Jagielloński, woj. lwowskie. 
około $15 \mathrm{~km}$ na zachód od Lwowa. Jego początki sięgają 1730 roku, kiedy to arcybiskup lwowski Jan Skarbek (1713-1733) podjął decyzję o powstaniu obiektu, gdyż droga do pałacu letniego w Dunajowie wydawała mu się zbyt odległa ${ }^{3}$. Swoje zamierzenie zaczął on wprowadzać w życie, ale niestety nie doczekał się finalizacji budowy i wyposażenia pałacu. Jego kolejni następcy na urzędzie metropolitów lwowskich kontynuowali z powodzeniem to dzieło i poświęcali mu sporo swojej uwagi. Najbardziej zaangażowani okazali się arcybiskupi: Mikołaj Ignacy Wyżycki (1737-1757), Wacław Hieronim Sierakowski (1760-1780) i Ferdynand Onufry Kicki (1780-1797). Pierwszy z wymienionych dokończył budowę pałacu i urządził znajdującą się wewnątrz kaplicę. Rozpoczął też zapewne wyposażanie wnętrz, które to dzieło kontynuował abp Sierakowski. On też założył obok oranżerie, w których hodowano najrozmaitsze gatunki roślin, pochodzące z najodleglejszych nawet regionów ówczesnego świata. Jego następca - abp Ferdynand Kicki - erygował w 1791 roku w Obroszynie rzymskokatolicką parafię i ufundował murowany kościół. Przypałacowy park w stylu francuskim powstawał wieloetapowo przez cały XVIII wiek ${ }^{4}$. W tym też stuleciu pałac szczycił się swoją największą świetnością, a wymienieni hierarchowie bardzo często w nim przebywali, niektórzy nawet w nim zmarli ${ }^{5}$.

Wiek XIX nie przyniósł niestety dalszego rozwoju podlwowskiej rezydencji. Arcybiskupi lwowscy z biegiem czasu coraz częściej i chętniej wybierali pobyt w samym Lwowie, który stawał się centrum życia politycznego, religijnego i społecznego Galicji. Kolejni hierarchowie nadal odwiedzali Obroszyn, ale traktowali go jedynie jako miejsce krótkotrwałego wypoczynku. Wskutek wymienionych realiów pałac zaczął podupadać, a pierwszy okres jego świetności zakończył się wraz z wybuchem I wojny światowej oraz następujących po niej wojnach z Ukraińcami (1918-1919) i z bolszewikami (1919-1920). W tym okresie uległo całkowitemu zniszczeniu niemal

\footnotetext{
3. Dunajów jest położony ok. $70 \mathrm{~km}$ na pd-wsch od Lwowa.

4. R. Aftanazy, Materiały do dziejów rezydencji, red. A. Baranowski, t. 7a Dawne województwo ruskie: Ziemia Halicka i Lwowska, Warszawa 1990, s. 374-375, 379; M. Dzieduszycki, Żywot Wacława Hieronima Sierakowskiego arcybiskupa lwowskiego, Kraków 1868, s. 256, 293, 302.

5. Byli to: Wacław Hieronim Sierakowski w 1780, Ferdynand Onufry Kicki w 1797 oraz niewymieniony wcześniej Kajetan Ignacy Kicki w 1812 r.
} 
całe ruchome wyposażenie oraz zostało zniszczone całe zaplecze gospodarcze. Wrogie wojska nie oszczędziły nawet oranżerii ${ }^{6}$.

Po odzyskaniu przez Polskę niepodległości abp lwowski Józef Bilczewski podjął decyzję o restauracji obiektu, wraz z zapleczem gospodarczym i parkiem, powierzając dzieło odnowy architektowi Bronisławowi Wiktorowi. Nadzór konserwatorski sprawował wojewódzki konserwator zabytków dr Józef Piotrowski. Poczynione przez Wiktora działania przekroczyły jednak granice zwykłej restauracji, a przybrały charakter daleko posuniętej przebudowy i modernizacji, zarówno w wyglądzie zewnętrznym, jak i wystroju wewnętrznym. Fakt ten nie spodobał się ówczesnej opinii publicznej, ale przeprowadzonych zmian nie można już było cofnąć $\dot{c}^{7}$ W takim stanie architektonicznym pałac zasadniczo przetrwał do dziśs

Zmiany w wyglądzie zewnętrznym pałacu w Obroszynie są szerzej znane i opracowane zwłaszcza w aspekcie ostatniej przebudowy ${ }^{9}$. Niestety, jak dotąd o samym wyposażeniu obiektu niewiele wiadomo. Ubolewał nad tym faktem cytowany już parokrotnie Roman Aftanazy, pisząc: "Nie wiadomo właściwie, jaki był w szczegółach wystrój sal i pokoi pałacu obroszyńskiego przed 1914 rokiem. Wiemy jedynie, że mimo zaniedbania cały urządzony był starymi meblami, sięgającymi epoki budowy i wieloma dziełami sztuki. Do najcenniejszych należała kompletna galeria portretów arcybiskupów lwowskich łącznie z wizerunkiem pierwszego metropolity halickiego, Krystyna z Ostrowa de Gozdawa. [...] Niestety, nie istnieje przypuszczalnie żaden inwentarz zbiorów obroszyńskich"10. Dodawał on też przy tym informacje o zniszczeniu wyposażenia w czasie I wojny światowej i następnych konfliktów z lat 1919-1920.

Niniejszy artykuł uzupełnia wspomnianą lukę w historii pałacu i jego wyposażenia dzięki odnalezieniu dwóch edytowanych poniżej inwentarzy, sporządzonych w 1885 roku oraz prawdopodobnie w 1900 roku. Ich

6. R. Aftanazy, Materiały do dziejów..., dz. cyt., s. 375; Inwentarz nr 2 -zob. poniższa edycja.

7. R. Aftanazy, Materiały do dziejów..., dz. cyt., s. 375-378.

8. Po wybuchu II wojny światowej, w 1939 r., okupujący Kresy Wschodnie II Rzeczypospolitej Sowieci, przejęli obiekt na własność i stan ten nie zmienił się do $1991 \mathrm{r}$. W tym czasie dokonali oni kolejnych przeróbek, m.in. dzieląc na dwie kondygnacje kaplicę pałacową. W pałacu umieścili Instytut Rolnictwa, który istnieje do dziś. Budynek wymaga remontu. R. Aftanazy, Materiały do dziejów..., dz. cyt., s. 377-378; Informacje własne autora artykułu.

9. Publikowano te informacje na łamach "Wiadomości Konserwatorskich" w $1924 \mathrm{r}$.

10. R. Aftanazy, Materiały do dziejów..., dz. cyt., s. 377. 
treść została wpisana do inwentarzy ziemskich kluczy majątkowych dóbr obroszyńskich ${ }^{11}$. Materiały te nie były wcześniej publikowane ${ }^{12}$.

Oba dokumenty w detalach przedstawiają urządzenie budynków gospodarczych, parku, a także, co najcenniejsze, wyposażenie samej rezydencji. Opis obiektów uwzględnia zawsze ich wymiary, podawane w sążniach i metrach (1885), bądź tylko w metrach (1900), przez co można również zyskać wyobrażenie wizualne. Dodatkowym atutem przy poszczególnych zapisach są odniesienia do poprzednich inwentarzy, przez co można pokusić się o śledzenie poszczególnych zmian na przestrzeni lat. Niejednokrotnie wymieniano również szacowaną wartość przedmiotów ${ }^{13}$, dzięki czemu można mieć pogląd co do ich drogocenności. Ten ostatni walor występuje rzadziej w inwentarzu z 1900 roku. Ostatnim ważnym elementem są załączone do inwentarza z 1885 roku unikatowe rzuty poszczególnych kondygnacji pałacu wraz z wymiarami pomieszczeń, a także plan sytuacyjny całego założenia parkowo-pałacowego. Na tych planach opiera się też charakterystyka pomieszczeń i całego obiektu.

Warto zwrócić uwagę na datację inwentarzy, gdyż nie jest ona przypadkowa. Zostały one bowiem sporządzone z okazji obejmowania urzędu metropolity przez poszczególnych hierarchów: abp. Seweryna Morawskiego w 1885 roku i abp. Józefa Bilczewskiego - 15 lat później. Ponadto warto zauważyć, że ów ostatni dokument zawiera też liczne adnotacje z 1923 roku, sporządzone przez ówczesnego zarządcę dóbr arcybiskupich archidiecezji lwowskiej ks. dr. Jakuba Demitrowskiego, co wskazuje na to, że uaktualnił

11. Archiwum Lwowskiej Kurii Metropolitalnej w Krakowie (Archiwum im. abp. Eugeniusza Baziaka w Krakowie przy Uniwersytecie Papieskim Jana Pawła II w Krakowie) [dalej: ALKMK], Archiwum Zarządu Dóbr Stołowych, sygn. 135, Inwentarz pałacu rezydencjalnego we Lwowie i dóbr w kluczu obroszyńskim należących do łac. arcybiskupstwa lwowskiego spisany i uzupełniony w roku 1884/5; sygn. 136, Pałac oraz klucz obroszyński, b. d. Oba egzemplarze nie posiadają paginacji.

12. W 2013 roku ks. Józef Wołczański opublikował w jednej ze swych monografii inwentarz kaplicy pałacowej w Obroszynie, ale wykorzystał do tego inny, niedatowany inwentarz, pochodzący z pierwszej połowy XX w. Co istotne, wymienia on częściowo przedmioty opisywane w edytowanych tutaj dokumentach. W edycji ks. Wołczańskiego nie znajduje się jednak odniesienie do ewentualnych poprzednich inwentarzy ani nie została też zawarta informacja o wartości przedmiotów. Inwentarz lwowskiej bazyliki metropolitalnej obrzadku łacińskiego kaplic rezydencji arcybiskupów we Lwowie i Obroszynie XIX/XX wieku oraz jego losy po II wojnie światowej w Polsce, opr. J. Wołczański, Lwów-Kraków 2013, s. 50-51.

13. W 1885 r. wyrażano ją w „walucie austriackiej”, czyli w złotych i centach, zaś w 1900 r. w koronach i halerzach. 
on inwentarz u progu rządów kolejnego metropolity - abp. Bolesława Twardowskiego ${ }^{14}$. Uzupełnienia te są niezwykle cenne, gdyż szczegółowo ukazują skalę zniszczeń spowodowanych wojnami z lat 1914-1920.

Najwięcej trudności w edycji inwentarzy sprawiły opisy dotyczące roślin hodowanych w oranżerii, gdyż okazało się, że w licznych przypadkach nazwy te podawano ze słyszenia, a tym samym zostały one obarczone różnymi błędami. W toku prac redakcyjnych zmodyfikowano łacińskie zapisy nazw roślin, głównie poprzez usunięcie literówek lub innych drobnych błędów, w celu większej rozpoznawalności poszczególnych gatunków i ich odmian. Okazało się również, że co najmniej kilkanaście gatunków wymienionych przez inwentarz, w ogóle nie występuje w literaturze botanicznej. W związku tym pozostawiono je w dotychczasowym brzmieniu. Być może zastosowane nazwy były tymczasowe, zasłyszane. Wiele z nich przez dziesięciolecia zmieniano czy też przeszeregowywano. Przykładem może być tutaj chociażby Dracaena Australis, której nazwa pochodzi z końca XVIII wieku, a obecnie roślina ta nazywa się Cordyline australis. Warto też zauważyć, że większość z roślin wymienionych w inwentarzach pochodziła z regionów tropikalnych i nawet współcześnie nie mają one polskich nazw. Z powyższych względów związanych z bogatą florą obroszyńskiej rezydencji zrezygnowano z typowej charakterystyki poszczególnych gatunków, zostawiając ją w sferze indywidualnych poszukiwań specjalistów z zakresu botaniki.

W opracowaniu niniejszej edycji zastosowano współczesne zasady edycji tekstów źródłowych oraz wprowadzono podwójny system oznaczania przypisów. Przypisy liczbowe odnoszą się do kwestii merytorycznych, zaś literowe do edytorskich.

14. Autorstwo adnotacji ustalono na podstawie analizy charakteru pisma, potwierdzając jego zgodność z osobą wspomnianego duchownego. 
1. Plan sytuacyjny założenia pałacowo-parkowego w Obroszynie, rys. W. Poźniak, Lwów, 1884

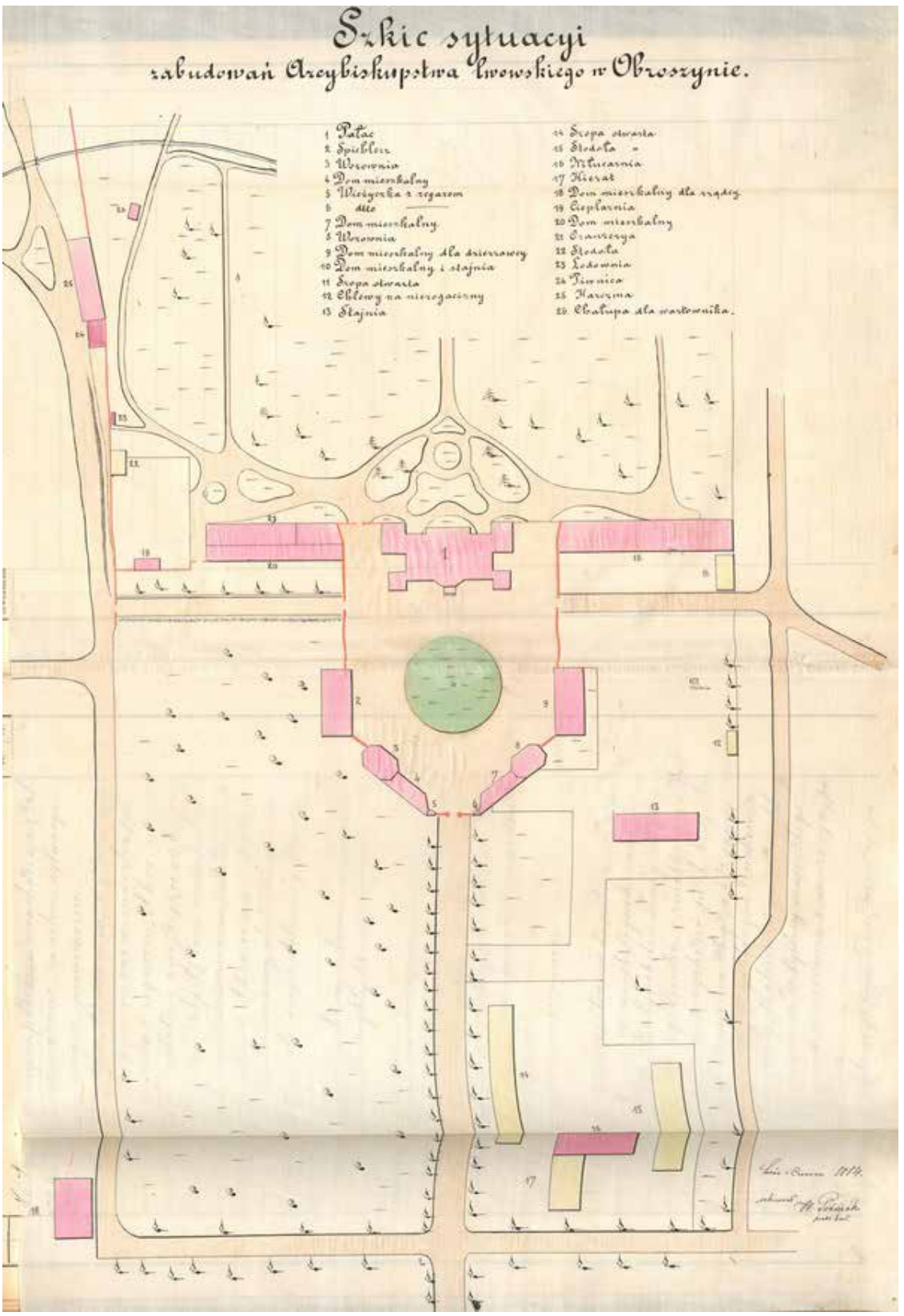




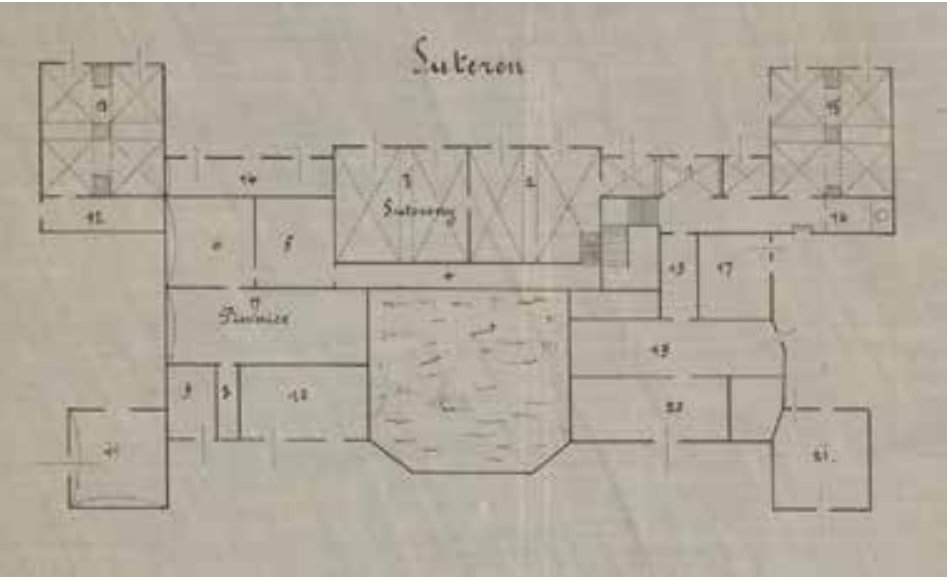

2. Rzut suteren pałacu w Obroszynie, rys. W. Poźniak, Lwów, 1884

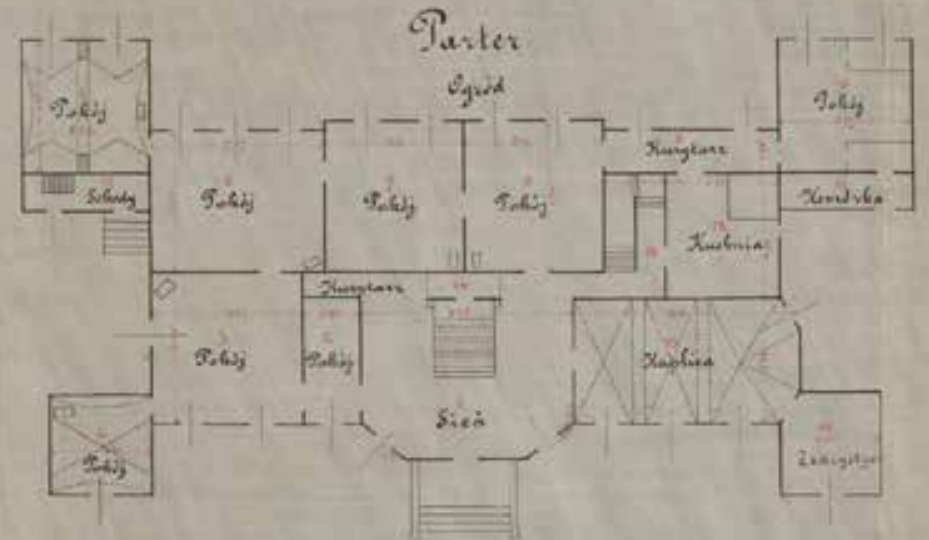

3. Rzut parteru pałacu w Obroszynie, rys. W. Poźniak, Lwów, 1884

4. Rzut I piętra pałacu w Obroszynie, rys. W. Poźniak, Lwów, 1884

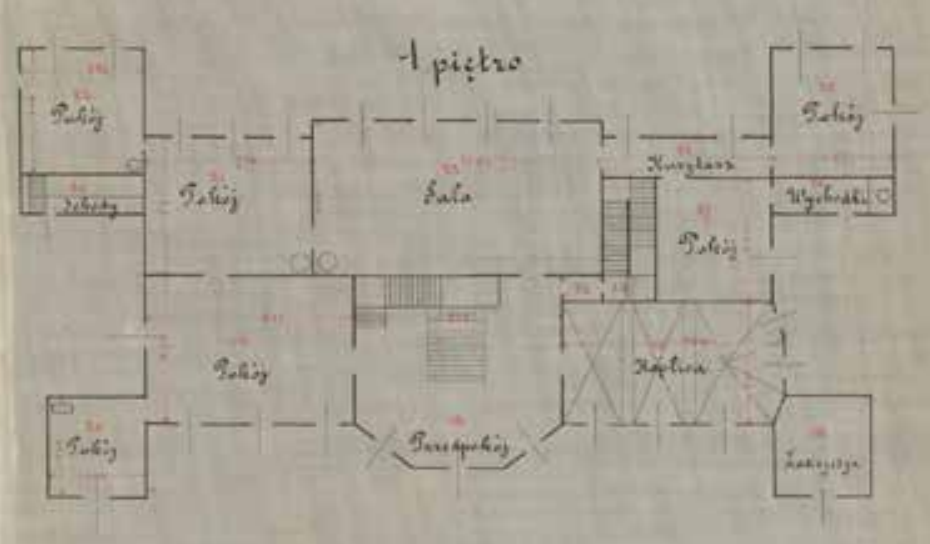




\section{Edycja źródła}

\section{Inwentarz z 1885 roku}

Majętność tabularna odda[lo]na około 10 kilometrów od miasta Lwowa, w której się znajduje rezydencja letnia arcybiskupa łac. Do takowej prowadzi od gościńca krajowego Zimnowodka ${ }^{15}$ - Hoszany ${ }^{16} \mathrm{w}$ lewo około figury św. Dominika ${ }^{17}$ droga prywatna obsadzona lipami, a przez bramę wjeżdża się na podwórze, okolone budynkami, a po części murem, w środku którego jest gazon a wprost bramy wjazdowej położony jest [pałac], jak dołączony szkic uwidacznia ${ }^{18}$.

Pałac, czyli rezydencja letnia arcybiskupa, na szkicu oznaczony numerem 1. Jest to budynek murowany, jednopiętrowy, do którego przystęp od podwórza przez cztery kamienne schody na ganek otwarty, a z tego przez drzwi, blachą żelazną okute do sieni z 2 oknami o kamiennej posadzce. Pośród tej sieni znachodzą ${ }^{19}$ się schody drewniane prowadzące na 1 piętro, po lewej zaś stronie prowadzą drzwi do 8 pokoi mieszkalnych w parterze położonych drzwiami między sobą połączonych. Z ósmego pokoju jest osobny korytarz, z którego na prawo jest przystęp do kuchni, z której osobne drzwi prowadzą na korytarz, stanowiący wraz [z] omówioną sienią jedną całość, a osobne drzwi od omówionego korytarza prowadzą do narożnego pokoju parterowego, obok którego na prawo znachodzi się komórka.

Z wstępnej sieni na prawo prowadzą drzwi do kaplicy, której wysokość sięga aż pod dach, o 3 oknach frontowych, z której drzwi prowadzą do małej zakrystii. Dołączony osobny szkic pałacu uwidacznia dokładniej położenie tych ubikacji.

Pod parterem znachodzą się suteryny i piwnice, a z suterenów ${ }^{20}$ prowadzą 2 wyjścia do ogrodu.

Na pierwszym piętrze, do którego przystęp przez schody ze sieni, znachodzą się najprzód obszerny przedpokój, na szkicu oznaczony nr 18. Po

\footnotetext{
15. Właśc.: Zimna Woda - wieś w pow. Lwów, woj. lwowskie.

16. Hoszany - wieś w pow. Rudki, woj. lwowskie.

17. Dominik (1175-1221), właśc. Domenigo Guzmán, święty Kościoła katolickiego, asceta, kaznodzieja, założyciel zakonu dominikanów, kanonizowany w 1234 roku przez papieża Grzegorza IX. Szerzej: J. Kłoczowski, Dominik, w: Encyklopedia Katolicka [dalej: EK], t. 4, Lublin 1985, kol. 60-61.

18. Zob. fot. 1.

19. Znachodzić - przestarzałe: znajdować. W całym dokumencie zapis zgodny z oryginałem.

20. Styl zgodny z oryginałem.
} 


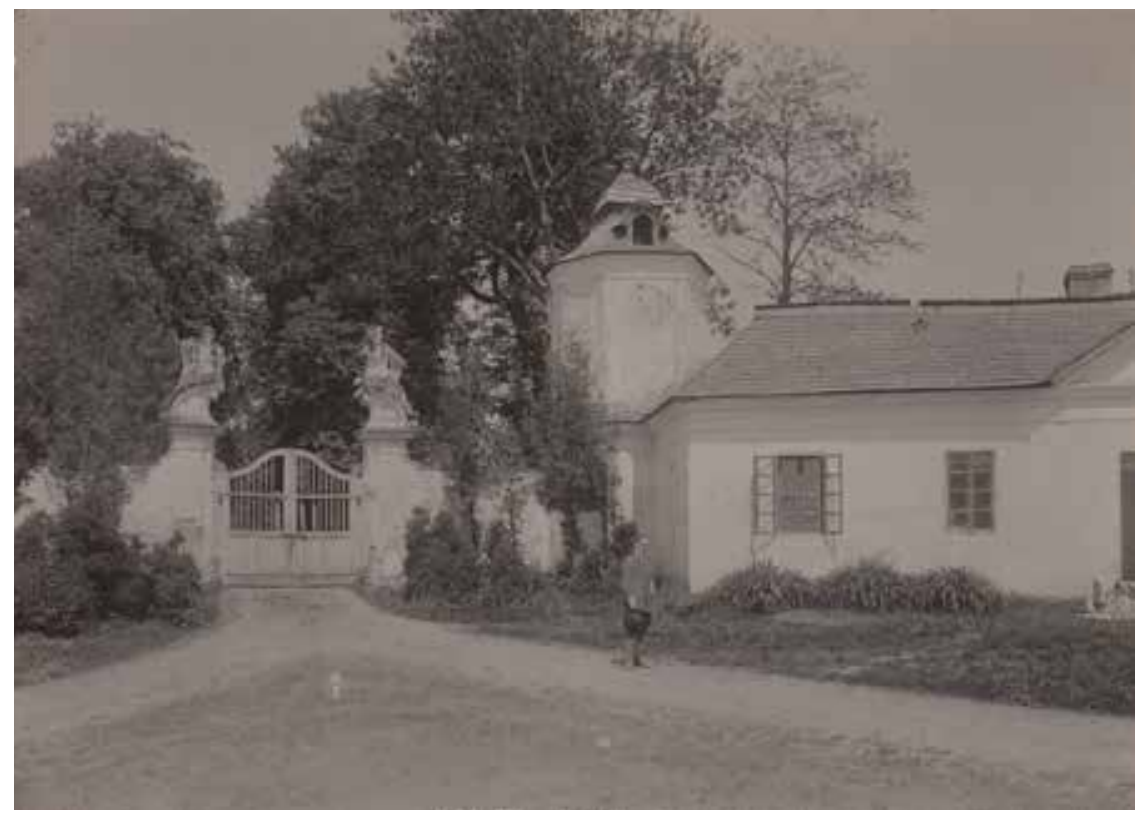
5. Brama
wjazdowa do pałacu, ok. 1923, fot. Bronisław Wiktor

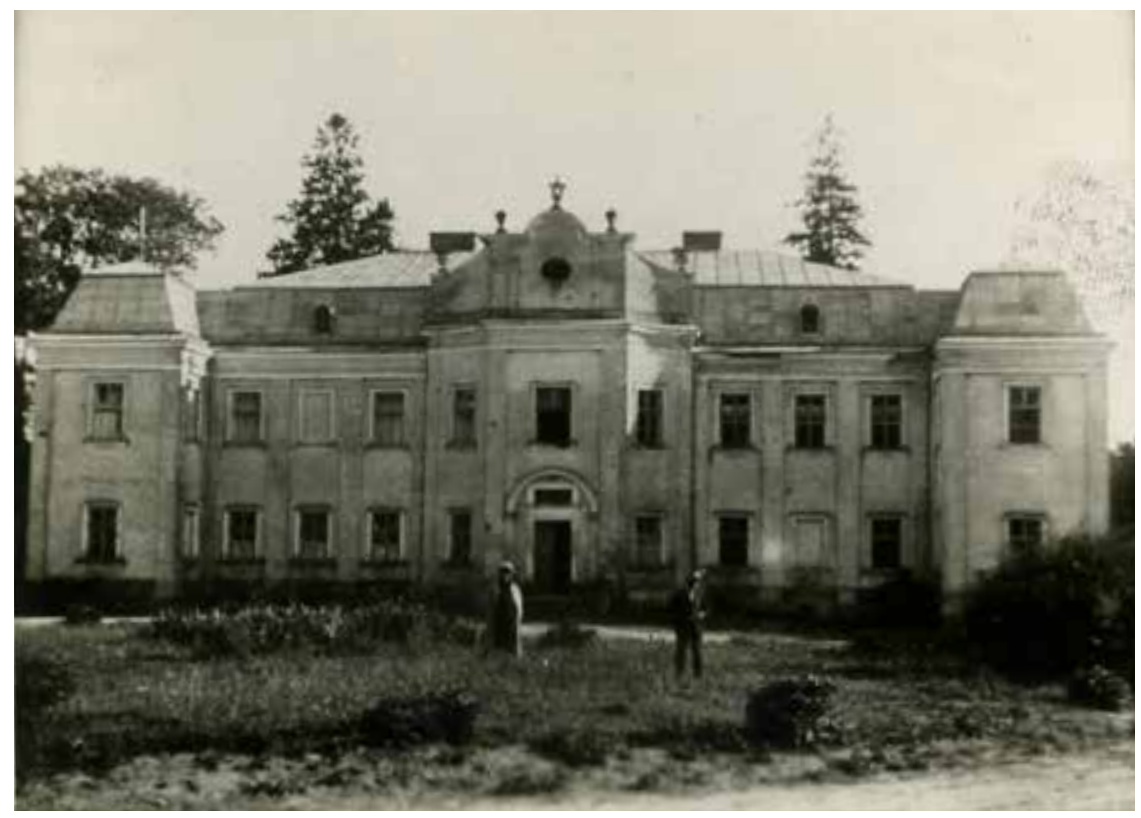

6. Widok ogólny pałacu przed renowacją, ok. 1922 
a. Obok na marginesie adnotacja: „ad. 1. W czasie interkalarnym [tj. w czasie wakansu - GCh] po śmierci ks. arcybiskupa Wierzchleyskiego wykonano około pałacu następujące restauracje na koszt funduszu interkalarnego, a to: mury tak z zewnątrz, jak z wewnątrz, otynkowana nowo na wysokość 1 sążnia i pobielono z zewnątrz, ponaprawiano miejscami gzymsy, ściany w pokojach pomalowano częścią na nowo, a częścią odświeżono dawniejsze malowidło, piece i kominki ponaprawiano, podłogi oszparowano i pokitowano, drzwi i okna polakierowano na nowo, sufity odeszczono i obwisłe sufity na 1 piętrze podciągnięto, wreszcie pobielono kuchnię i boczne ubikacje. Koszta poniesione na te roboty wynoszą [brak wpisanej kwoty]. W czym objęte są także koszta naprawy tynków z zewnątrz przy budynkach okalających dziedziniec pałacowy a oznaczonych na planie sytuacyjnym L.2 do 9.". Pałac, wraz z opisem najbliższych mu budynków, zapisano w niniejszym inwentarzu pod liczbą bieżącą 1 (w poprzednim inwentarzu -2 ). lewej strony [sic] z przedpokoju prowadzą drzwi do loggii w kaplicy się znajdującej, a po prawej stronie drzwi do 4 pokoi mieszkalnych i dużej sali o 4 oknach z widokiem na ogród, w których się znachodzą portrety byłych arcybiskupów lwowskich. Z tejże sali prowadzi korytarz o 2 oknach do 2 odrębnych pokoi (nr 25 i 27), a z pokoju nr 27 jest przystęp do wychodków nr 26.

Z przedpokoju obok kaplicy $(\mathrm{nr} 28,29)$ prowadzą osobne schody na strych, a obok pokoju nr 22 pierwszego piętra znachodzą się schody nr 30, na razie zamurowane, prowadzące z pierwszego piętra i parteru (nr 17 szkicu) na podwórza.

W[e] wszystkich pokojach są piece ogrzewalne dawniejszej konstrukcji, okna dwuskrzydłowe, podwójne, ściany malowane, a podłogi częściowo z twardego, częściowo z miękkiego materiału w tafle układane. Dach budynku jest gontem kryty.

Stan budynku dobry, należyta konserwacja jednak wymaga niektórych pomniejszych restauracji, a mianowicie naprawy tynku odpadającego na podnóżu budynku, który nie posiada właściwego cokołu, dalej naprawy w niektórych miejscach facjat zewnętrznych, dalej naprawy częściowo zamokniętego sufitu w narożnym pokoju 1-go piętra (nr 25), w którym na razie umieszczoną jest prowizorycznie kuchnia, ostatecznie naprawy dachu nad tymże pokojem, przez pobicie gontami.

Wartość pałacu $-25000 \mathrm{zł}^{\mathrm{a}}$

Na tymże samym podwórzu znachodzą się dalsze budynki murowane na szkicu sytuacji nr 2 do 9 oznaczone, mianowicie:

$\mathrm{N}[\mathrm{r}] 2$ szkicu spichlerz, $\mathrm{n}[\mathrm{r}] 3$ wozownia, $\mathrm{n}[\mathrm{r}] 4$ dom mieszkalny, w którym na razie mieszka praczka, n[r] 5 wieżyczka z zegarem, n[r] 6 również wieżyczka, obydwie ostatnie znajdujące się tuż przy bramie wjazdowej, dalej n[r] 7 dom mieszkalny, w którym na razie umieszczona jest kuchnia dzierżawcy, następnie n[r] 8 wozownia in[r] 9 
dom mieszkalny dla dzierżawcy, obok którego znachodzi się nowo założony i płotem ogrodzony ogródek.

Wszystkie te budynki są w stanie należytym i wymagają tylko zwykłej konserwacji, mianowicie w wyprawie.

Wartość tych budynków wynosi razem $6250 \mathrm{zł}$.

Prócz omawianych budynków, znachodzą się w podwórzu mury, a to po prawej i lewej stronie pałacu, zamykające podwórze, w których znachodzą się dwuskrzydłowe bramy, należycie okute, prowadzące do dróg prywatnych.

Wartość tych murów wynosi $100 \mathrm{zł.}$

Przy drodze, po prawej stronie od pałacu wiodącej, znachodzi się murowany budynek na szkicu oznaczony $\mathrm{n}[\mathrm{r}]$ 20. Budynek ten służy na pomieszkanie dla ogrodnika i parobków, a w starym inwentarzu przychodzi pod L.b. 17. Budynek ten jest 24 sążnia długi, a 51/2 sążni szeroki, murowany, pod gontowym dachem, z frontu ma 4 wchody, 10 okien i ganek oszklony, w czole zaś 2 okien, a do tylnej części tego budynku przypiera murowana oranżeria, położona w ogrodzie.

Z ganku oszklonego prowadzą drzwi do pomieszkania ogrodnika, które jest połączone dalszymi drzwiami z omówioną oranżerią. Od frontu jest drugi wchód do stajenki, trzeci wchód od frontu do mieszkań parobków, a czwarty do małego chlewka. Dach nad całym budynkiem jest dobry, podłogi atoli w izbach mieszkalnych pogniły, w ogóle zaś stan budynku średni, a wartość takowego $2500 \mathrm{zł}^{21}$

Naprzeciw tego budynku, wzdłuż drogi na lewo, znachodzi się sad, a po prawej stronie za tym budynkiem znachodzi się drzwi prowadzące do parku, położonego

21. Budynkowi nr 20 nadano w inwentarzu nr 2, a w dawnym inwentarzu wpisano go pod nr. 17.

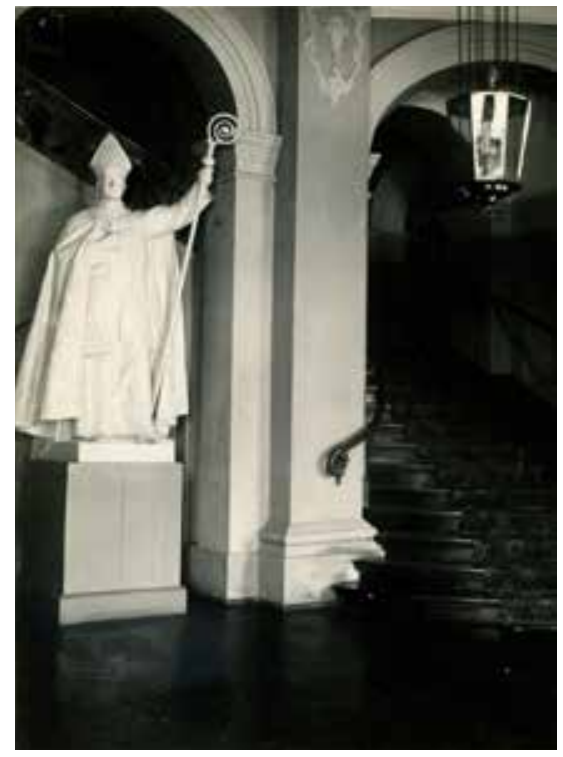

7. Sień wejściowa i pomnik abp. Józefa Bilczewskiego, po 1924

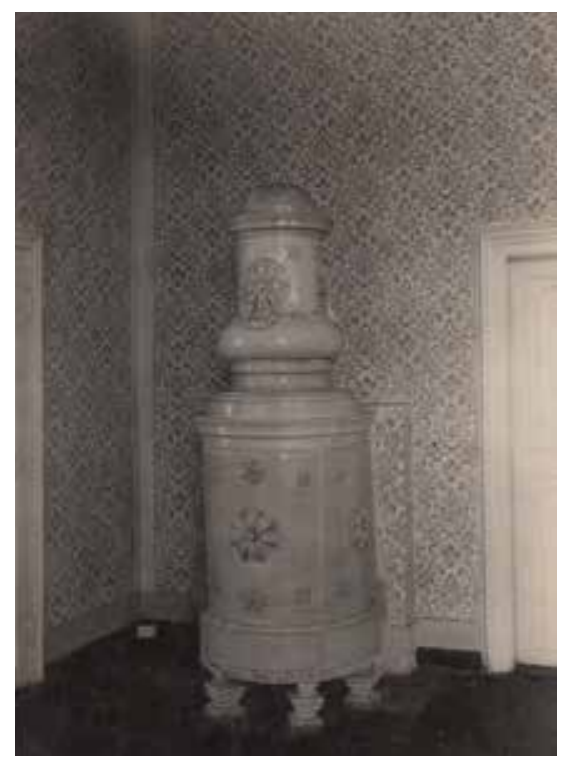

8. Piec kaflowy, ok. 1923, fot. Bronisław Wiktor 
9. Widok pałacu od strony

ogrodu, po 1924

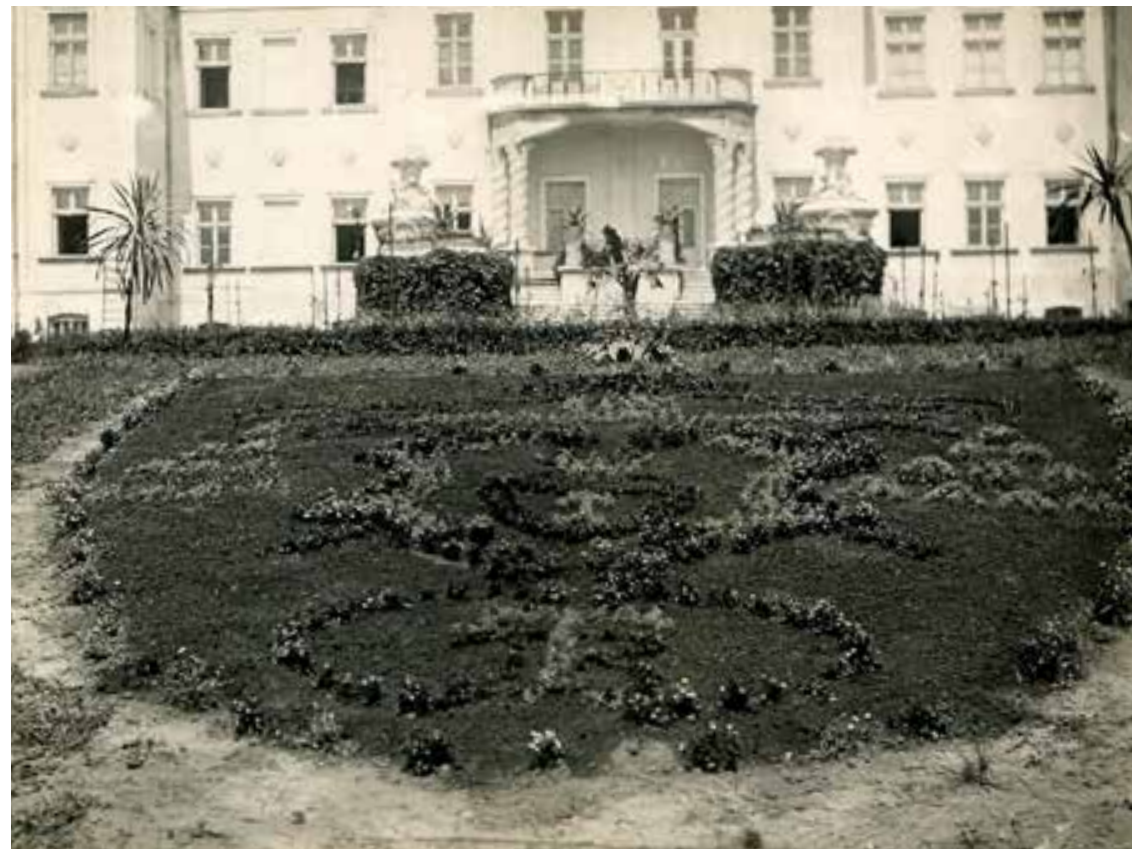

10. Widok wnętrza, ok. 1923 ,

fot. Bronisław Wiktor

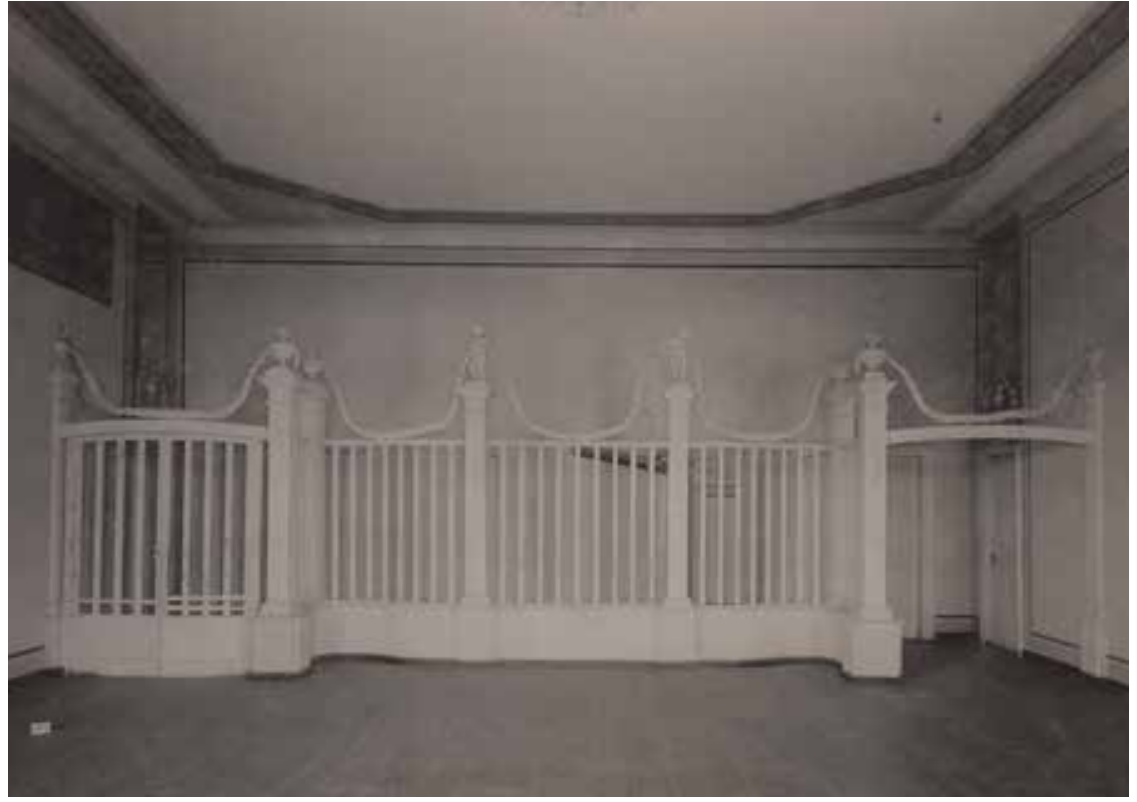


wzdłuż tej drogi, niemniej drogi do Basiówki ${ }^{22}$ i dalszej drogi do Bartatowa $^{23}$ prowadzącej i który przytyka do pałacu i budynków pałacowych.

Park ten jest dawno założony i w takowym znajdują się aleje świerkowe i grabowe, niemniej 2 stawki, nieco drzew owocowych, następnie oranżeria murowana oznaczona na szkicu sytuacji n[r.] 21, która w założeniu swoim celowi swemu niezupełnie jest odpowiednią, w takowej strop z belek i ściele na tymże są zupełnie zbutwiałe, tak mocno, iż wymagają zupełnego odnowienia. Belki w nagłówkach najbardziej nadpsute są jednak w szklarni podstemplowane i mogą na razie być dalej prowizorycznie podparte.

Dalej znachodzi się w ogrodzie cieplarnia oznaczona na szkicu n[r.] 19, murowana i oszklona. Obok tej cieplarni znajdują się inspekta, następnie znachodzi się przy inspektach mała stodółka oznaczona na szkicu n[r.] 22, dalej lodownia oznaczona n[r.] 23, ostatecznie n[r.] 26 suszarnia, a względnie chałupa dla wartownika.

Park od strony drogi do Basiówki wiodącej otoczony jest murem, który atoli w jednej części, tj. tuż przy karczmie, potrzebuje nowego odbudowania, gdyż u podnóża tegoż wskutek upływu czasu, a nie wskutek zaniedbania, cegły przewilgły i zgniły, przeto mur w tej części pochylił się ku ogrodowi i musiał być podpartym, celem zapobieżenia zawalenia się. Odbudowania tej części, według zapodania technika wystarczy do wysokości 2,30 m terenu zewnętrznego w miejsce dotychczasowej, wyższej wysokości.

W dalszej części otoczony jest ogród płotem z chrustu, który również wskutek upływu czasu potrzebuje odnowienia.

Wartość oranżerii, cieplarni i reszty budynków w ogrodzie położonych wraz z murem i płotami, z uwzględnieniem stanu dzisiejszego wynosi $3500 \mathrm{zł} .^{\mathrm{b}}$

Od pałacu wychodząc bramą po lewej ręce położoną ku drodze do Bartatowa prowadzącej, znachodzi się budynek murowany, oznaczony na szkicu sytuacji n[r] 10 długości 301/2 sążni z szerokości 5\%1/3 sążnia, który przypiera do parku. Budynek ten ma z frontu 3 wchody do osobnych oddziałów, pierwszy oddział stanowi mieszkanie dla stróża pałacowego i furmana, drugi oddział zajmują dwie z sobą połączone stajnie na konie z żłobami i drabinami, trzeci oddział jest wozownia.

22. Basiówka - wieś w pow. lwowskim, woj. lwowskie.

23. Bartatów - wieś w pow. Gródek Jagielloński, woj. lwowskie. b. Na marginesie adnotacja: „ad. 3. W czasie interkalarnym, po śmierci ks. arcybiskupa Wierzchleyskiego, pobito na oranżerii stronę dachu od południa i z obu przyczółków nowymi gontami, a w oranżerii dano nową powałę z desek i zaciągnięto nowe belki powałowe. Również pobito na nowo daszek nad cieplarnią (ananasarnią). Powała nad oranżerią wylepiona z wierzchu gliną". Park, cieplarnia, oranżeria i pozostałe budynki zapisano w inwentarzu pod nr. 3. W dawnym nie uwzględniono. 
c. Na marginesie z prawej strony, prawdopodobnie późniejsza niż inwentarz, adnotacja: „ad. 9. Poszycie dachu na stodole od północnej i zachodniej strony, tudzież całe poszycie dachu nad budynkiem kieratowym jest w złym stanie". Obiekt zapisano w cytowanym inwentarzu pod nr. 9, w dawnym -22 .
W całym budynku są powały z desek, dach gontem pokryty, nad wozownią nowo pobity, zaś w dalszych częściach dawny, nieco nadpsuty, ściany budynku wymagają nowego wytynkowania dołem.

Stan budynku średni, wartość $2800 \mathrm{zł.}^{24}$

Tuż obok tego budynku stoi poddasze otwarte i oparte na 9 słupach, pod gontowym dachem, służący na skład na wozy. Długość tego poddasza wynosi $14 \mathrm{~m}$, a szerokość 6,50 m.

Stan średni, wartość $10 \mathrm{zł.}$

Przy tym poddaszu znachodzi się brama wjazdowa między dębowymi słupami, przypierającymi do murowanych filarów i która zamyka położone wewnątrz podwórze gospodarcze okolone płotem z chrustu ${ }^{25}$.

Na tym podwórzu gospodarczym znachodzi się najprzód studnia cembrowana, z wałem i 2 wiadrami. Druga studnia z drewnianą pompą znachodzi się w ogrodzie, tuż przy oranżerii.

Wartość obu studzien $160 \mathrm{zł.}^{26}$

Dalej za studnią, obok płotu granicznego, jest mały chlew, oznaczony na szkicu sytuacji n[r] 12, drewniany, pod słomianym dachem wybudowany ze starego materiału. Długość chlewa wynosi 8 m, a szerokość $4 \mathrm{~m}$.

Stan średni, wartość $20 \mathrm{zł} .^{27}$

Stajnia na krowy murowana, 14 sążni długa a 4²/2 sążnia szeroka, pod gontowym dachem będącym w dobrym stanie, mury zaś stajni wymagają wytynkowania.

Stan budynku średni, wartość $1000 \mathrm{zł.}{ }^{28}$

Oznaczony na planie sytuacji n[r] 16 budynek [to] jest stodoła murowana wraz z kieratem pod słomianym dachem. Kierat, tj. budynek kieratowy, przybudowany w nowszych czasach, jest na dębowych słupach, a ściany tegoż plecione z chrustu. W stodole tej są podwójne dwuskrzydłowe wrota. Stan budynku dobry, wartość $900 \mathrm{zł} .^{\mathrm{c}}$

24. Budynek zapisano w niniejszym inwentarzu pod nr. 4, w dawniejszym - 18.

25. Poddaszu i bramie nadano nr 5. Poprzedni inwentarz ich nie uwzględniał tej pozycji.

26. Studniom nadano tutaj nr 6. Poprzedni inwentarz nie uwzględniał.

27. Zapisany pod nr. 7. Stary inwentarz go nie uwzględniał.

28. Stajnia wpisana pod nr. 8, w dawnym inwentarzu pod nr. 26. 
Szopa otwarta, spoczywająca na słupach, o dachu pokrytym trześnią, która atoli w ubiegu czasu przez burzę mocno ucierpiała, ku jednej stronie jest nachyloną i ma niektóre załamany [sic] płatwy. Budynek ten grozi zawaleniem się. Stan ten atoli nastąpił według wywodu technicznego, wskutek zgnicia odziomków słupów w ziemię wkopanych, budynek ten wymaga przeto bezzwłocznego podparcia (szkic nr 14). Stan zły ${ }^{29}$.

W miejscu dawnej szopy o plecionych ścianach stanęła za czasów arcybiskupa śp. Ks. Wierzchleyskiego ${ }^{30}$ szopa otwarta pod słomianym dachem, spoczywająca na 33 słupach dębowych, a oznaczona na szkicu sytuacji nr 15. Takowa jest $36 \mathrm{~m}$ długa, 10,50 m szeroka, stan dobry, a wartość 600 zł. ${ }^{31}$

Poza ogrodem owocowym znachodzi się murowany jednopiętrowy budynek, oznaczony na szkicu sytuacji n[r.] 18, służący na mieszkanie dla rządcy dóbr.

Dach gontem kryty. W parterowej części budynku tego są dwie stajenki, następnie drewutnia, wozownia i mała komórka. Pod parterem znachodzą się 2 piwnice.

Do pierwszego piętra prowadzą schody, z sieni parterowej, a na tymże znachodzi się kuchnia angielska z piecem piekarskim, dalej spiżarka z ogniskiem angielskim, sześć ubikacji mieszkalnych i dwa przedpokoje. Wszystkie ubikacje mają podłogę z desek.

Stan budynku jest dobry, a wartość takowego wynosi $4000 \mathrm{zł.}^{32}$

Obok muru okalającego park pałacowy przy drodze do Basiówki wiodącej, znajduje się murowana karczma, oznaczona na szkicu sytuacji n[r.] 25, pod

29. Nie podano wartości obiektu. Zapisano go pod nr. 10, dawniejszym 23. Obok na marginesie późniejsza adnotacja: „ad. 10. Szopa ta zawaliła się podczas interkalarza w roku $1884 "$.

30. Wierzchleyski Franciszek Ksawery (1803-1884), święcenia kapłańskie w 1826 roku, duszpasterz w Kalwarii Zebrzydowskiej, Lwowie i Gołogórach k. Złoczowa, od 1845 roku kanonik lwowskiej Kapituły Metropolitalnej, biskup przemyski 1846-1860, arcybiskup lwowski 1860-1884. H. Borcz, Wierzchlejski [sic] Franciszek Ksawery, w: EK, t. 20, Lublin 2014, kol. 546.

31. Budynek zapisano pod nr. 11, dawnym -24 .

32. Budynek otrzymał w cytowanym inwentarzu nr 12, a w dawniejszym 31. Obok tegoż obiektu, na prawym marginesie, późniejsze adnotacje: „ad. 12. Rozebrany wskutek zezwolenia c. k. Namiestnictwa z 27 listopada 1893 L.90923, a wykreślony na podstawie reskryptu c. k. Namiestnictwa z 2/8 1895 L.61510 N.E.302/XIII, Lwów, 10 sierpnia 1895, [podpisał:] Hilchen, Sekretarz Zarządu". Poniżej późniejsza adnotacja: „17/6 1923: Z cegły pozostałej po rozebranym budynku mandatarii wybudowano budynek szkoły, obecnie będący własnością Bęgowskiej". 
gontowym dachem, który jest w dobrym stanie. Budynek jest 15 sążni długi, a 5 sążni szeroki, ma z frontu 6 okien i 2 osobny [sic] wchody.

Pierwszy wchód prowadzi do sieni karczmy, z której na prawo prowadzą drzwi do izby szynkownej, a od tej dalsze drzwi do alkierza, w którym znachodzi się wchód do piwnicy umieszczonej poza budynkiem. Nad piwnicą tą jest odrębny dach, który jednak wymaga nowego pobicia, gdyż gonty zgniły już zupełnie.

Z sieni na lewo prowadzą drzwi do 5 z sobą połączonych ubikacji mieszkalnych. Pierwsza ubikacja ma podłogę z cegieł, dalej drzwi pojedyncze na prawo prowadzące go komórki i dalsze drzwi vis- $a$-vis ${ }^{33}$ wchodowych, prowadzących do dalszych cztery [sic] ubikacji. W tych ubikacjach jest podłoga z desek, która w ostatnich dwóch jest w złym stanie.

Z sieni wprost drzwi wchodowych prowadzą osobne drzwi do komórki, w której się znachodzą schody na strych. W ubikacjach tych są okna podwójne, drzwi na zawiasach.

Drugi wchód od frontu prowadzi do stajni na 8 sztuk bydła, ze żłobami i drabinami. Nad dachem znajdują się 3 murowany [sic] kominy, z których jeden wymaga otynkowania.

Stan budynku średni - wartość $1300 \mathrm{zł.}{ }^{34}$

Budynki powyż[ej] opisane odebrałem:

Obroszyn, 9 lipca 1885

Ks. Andrzej Mazurak ${ }^{35}$

Romuald Morawski ${ }^{36}$

33. Łac.: vis-a-vis - naprzeciwko.

34. Budynek zapisano pod nr. 13, a w dawniejszym inwentarzu pod pozycją 30.

35. Andrzej Mazurak (1829-1896), święcenia kapłańskie w 1861 we Lwowie, wikariusz par. Krzywcze 1861-1863, wikariusz par. Stryj 1863-1864, superior i ojciec duchowny w Małym Seminarium we Lwowie 1864-1873, katecheta w Gimnazjum im. Franciszka Józefa 1867-1873, kanonik Kapituły Metropolitalnej i asesor Konsystorza we Lwowie 1873-1896, dziekan-infułat tejże kapituły 1895-1896, egzaminator prosynodalny 1873-1896, sędzia archidiecezjalnego sądu małżeńskiego 1878-1896, długoletni członek Rady Miasta Lwowa, dyrektor Zakładu Głuchoniemych we Lwowie 1896. Catalogus universi venerabilis cleri saecularis et regularis archidioecesis Leopoliensis rit. lat., Leopoli 1861-1897, passim; † Ks. Andrzej Mazurak, "Gazeta Lwowska" 1896 nr 7, s. 3.

36. Romuald Morawski, młodszy brat arcybiskupa lwowskiego Seweryna Morawskiego (1885-1900) i zarządca dóbr arcybiskupich w okresie jego rządów. Mieszkał w pałacu arcybiskupów lwowskich we Lwowie. ALKMK, S. Morawski, Mój dziennik, t. 19: 1885-1886, passim; t. 22: 1888-1889, passim; t. 26: 1893-1895, passim. 
Ks. arcybiskupa łac.

Odbierający

Wobec c. k. Komisji:

Leopold Szabel ${ }^{37}$

Mieczysław Komarnicki ${ }^{38}$

c.k. radca Namiestnictwa

c. k. oficjał rach[unkowy] Namiestnictwa

37. Leopold Szabel (1832-1897), kawaler orderu Żelaznej Korony III klasy, właściciel majątku Ludwinów k. Jaworowa, od 1858 roku nieprzerwanie w państwowej służbie urzędniczej, urzędnik w urzędach cyrkularnych w Sanoku, Brodach i Przemyślu, pracownik Ministerstwa Spraw Wewnętrznych w Wiedniu 1865-1878, radca c. k. Namiestnictwa we Lwowie, a w nim kierownik departamentu dla spraw wyznania katolickiego 1878-1897, pochowany w Jaworowie; cieszył się powszechnym szacunkiem społecznym. † Leopold Szabel, "Gazeta Lwowska" 1897 nr 225, s. 2; Zmarli, „Słowo Polskie" 1897 nr 231, s. 3.

38. Mieczysław Komarnicki, pracownik oddziału rachunkowego c. k. Namiestnictwa, jako: asystent 1873-1884, oficjał 1885-1889, rewident 1890-1894, radca oddziału 1895-1899, nadradca 1900-1903, dyrektor 1904-1908. Szematyzm Królestwa Galicji i Lodomerii z wielkiem księstwem krakowskiem, Lwów 1873-1908, passim. 
d. Obok, na marginesie, adnotacja ołówkiem: "2 obrazki we Lwowie".

Sprzęty i aparaty kościelne w kaplicy pałacowej w Obroszynie

\begin{tabular}{|c|c|c|c|c|}
\hline \multicolumn{2}{|c|}{ L[iczba] bieżąca } & & \multirow{2}{*}{\multicolumn{2}{|c|}{ A. W. }} \\
\hline Nowego & Starego & & & \\
\hline \multicolumn{2}{|c|}{ Inwentarza } & & zł & $\mathrm{ct}$ \\
\hline 1. & $1,2,3,4$ & $\begin{array}{l}\text { Wielki ołtarz z gipsowej mozaiki, a w tym: duży } \\
\text { pozłacany krzyż drewniany, } 2 \text { biało pokostowane } \\
\text { anioły trzymające godła męki, zaś po bokach ołta- } \\
\text { rza dwanaście obrazy [sic] św. Apostołów }{ }^{\mathrm{d}}\end{array}$ & - & \\
\hline 2. & 5 & Dwa boczne ołtarzy [sic] z gipsowej mozaiki & & \\
\hline 3. & $1 / \mathrm{H}$ & $\begin{array}{l}\text { Ornat z białego atłasu w haftowane jedwabiem } \\
\text { kwiaty, obszyty wąskimi złotymi bortami, pod- } \\
\text { szywka żółta }\end{array}$ & 10 & \\
\hline 4. & $3 / \mathrm{H}$ & Pięć stuł w różnych kolorach & 5 & \\
\hline 5 . & $2 / \mathrm{I}$ & Komeżka muślinowa koronką obszyta & 2 & \\
\hline 6. & $1 / \mathrm{K}$ & Dwa perkalowy [sic] obrusy na ołtarz & 1 & \\
\hline 7. & $6,7 / \mathrm{K}$ & $\begin{array}{l}\text { Dzwonek na ścianie przy wchodzie do zakrystii, } \\
\text { tudzież jeden mały dzwonek ołtarzowy }\end{array}$ & 2 & 50 \\
\hline 8. & 9 & Klęcznik drewniany & & 20 \\
\hline 9. & 10 & Konfesjonał pokostowany & 2 & \\
\hline 10. & 11 & Fotel zielono obity a przed tym pult na książkę & 5 & \\
\hline 11. & 12 & Dwie ławki ciemno pokostowane & 6 & \\
\hline 12. & 13 & Dwie włóczką haftowane poduszki ołtarzowe & 3 & \\
\hline 13. & 14 & Czerwone sukno na ołtarz & 2 & \\
\hline 14. & 20 & $\begin{array}{l}\text { Drewniany postument pod lampę z blaszanym } \\
\text { koszem na lampę w kształcie serca }\end{array}$ & & 30 \\
\hline 15 . & 21 & $\begin{array}{l}\text { Żelazny stołek (faldistorium }{ }^{39} \text { ) z nakryciem sukien- } \\
\text { nym }\end{array}$ & 1 & \\
\hline 16. & 22 & $\begin{array}{l}\text { Przyrząd do mycia w zakrystii, a mianowicie postu- } \\
\text { ment drewniany, miednica zaś i kociołek na wodę } \\
\text { cynowe }\end{array}$ & 2 & \\
\hline 17. & 23 & Mała mosiężna monstrancja recte ${ }^{40}$ relikwiarzyk & 5 & \\
\hline 18. & - & Sześć cynowych lichtarzy ołtarzowych & 3 & \\
\hline 19. & - & Mały alabastrowy kociołek na wodę święconą & & 50 \\
\hline
\end{tabular}

39. Składane krzesło o 4 nogach, z niskim oparciem dla ramion, lecz bez oparcia dla pleców. Służy jako namiastka tronu biskupiego.

40. Łac.: recte - właściwie. 


\begin{tabular}{|c|c|c|c|c|}
\hline 20. & - & $\begin{array}{l}\text { Szafka z miękkiego drzewa z } 3 \text { szufladami - stara } \\
\text { zużyta }\end{array}$ & 1 & \\
\hline 21. & $1 / \mathrm{L}$ & Obraz św. Jana ${ }^{41}$ w pozłacanych ramach & 2 & \\
\hline 22. & 2 & Obraz św. Bernarda ${ }^{42}$ w pozłacanych ramach & 2 & \\
\hline 23. & 3 & $\begin{array}{l}\text { Obraz św. [Marii] Magdaleny }{ }^{43} \text { spożywającej wie- } \\
\text { czerzę, nad bocznym ołtarzem }\end{array}$ & 1 & \\
\hline $24^{44}$ & 4 & Dzieciątko Jezus z wosku w szklanym pudełku & & 30 \\
\hline 25 & 5 & $\begin{array}{l}\text { Obraz Chrystusa na krzyżu i [św.] Marii Magdale- } \\
\text { ny w pozłacanych ramach }\end{array}$ & & 50 \\
\hline 26. & 6 & $\begin{array}{l}\text { Obraz Matki Boskiej na bocznym ołtarzem [sic] po } \\
\text { lewej ręce }\end{array}$ & 1 & \\
\hline 27. & 7 & Obraz Chrystusa z wosku & & 30 \\
\hline 28. & 12 & $\begin{array}{l}\text { Obraz na płótnie Matki Boskiej z Dzieciątkiem } \\
\text { Jezus, w pozłacanych ramach }\end{array}$ & 1 & 30 \\
\hline 29. & 13 & Obraz Jezusa Chrystusa w pozłacanych ramach & & 3 \\
\hline 30. & $1 / \mathrm{M}$ & Missale Romanum ${ }^{45}$ w czerwoną skórę oprawione & 2 & \\
\hline 31. & 2,3 & Ceremoniale Episcoporum ${ }^{46}$, oprawne, 2 egzemplarze & 1 & 30 \\
\hline 32. & 4 & Canon Missae Pontificalis ${ }^{47}$ & & 30 \\
\hline 33. & 5 & Thesaurus sacrorum rituum ${ }^{48}$, w skórę oprawne & & 50 \\
\hline 34. & 6 & Martyrologium ${ }^{49} \mathrm{w}$ skórzanej oprawie & & 30 \\
\hline 35. & 7 & Ritualis altera pars ${ }^{50} \mathrm{w}$ skórzanej oprawie & & 50 \\
\hline
\end{tabular}

41. Obraz przedstawiał zapewne Jana Apostoła, ewangelistę, rybaka znad jeziora Genezaret, jednego z pierwszych uczniów Jezusa.

42. Był nim zapewne Bernard z Clairvaux (1090-1153), cysters, święty Kościoła katolickiego, filozof, teolog, doktor Kościoła, nazywany "niekoronowanym władcą" Europy, reformator życia klasztornego. Szerzej: S. Kędziora, J. Misiurek, Bernard z Clairvaux, w: EK, t. 2, Lublin 1985, kol. 301-302.

43. Imię uzupełniono w oparciu o dane z inwentarza z 1900 roku. Maria Magdalena lub Maria z Magdali, święta Kościoła katolickiego, pierwsza wśród kobiet towarzyszących Jezusowi w czasie Jego publicznej działalności oraz naoczny świadek Jego śmierci i zmartwychwstania. Szerzej: S. Szymik, Maria Magdalena, Maria z Magdali, w: EK, t. 11, Lublin 2006, kol. 1319-1320.

44. Pozycje pod numerami 24 i 25 w oryginale są zamienione. Aby zachować przejrzystość, zdecydowano o ich zamianie zgodnie z rzeczywistą kolejnością.

45. Mszał rzymski.

46. Księga obrzędowa dla biskupa, zawierająca przepisane przy kościelnych czynnościach obrzędy.

47. Kanon Mszy biskupich, obejmujący cichą Mszę św. od Sanctus do Paternoster (definicja zgodna z ówczesną terminologią).

48. Skarbnica świętych obrzędów (księga liturgiczna).

49. Zestawienie uznanych przez Kościół świętych i męczenników. Księgę używano przy nabożeństwie w chórze oraz w zakonach.

50. Dosłownie: obrzędowa druga część. Prawdopodobnie był to bliżej nieokreślony zbiór obrzędów liturgicznych. 
Sprzęty pokojowe w pałacu w Obroszynie

\begin{tabular}{|c|c|c|c|c|}
\hline \multicolumn{2}{|c|}{ L[iczba] bieżąca } & & \multirow{2}{*}{\multicolumn{2}{|c|}{ A. W. }} \\
\hline Nowego & Starego & & & \\
\hline \multicolumn{2}{|c|}{ Inwentarza } & & $\mathrm{zł}$ & ct. \\
\hline 1. & $\begin{array}{c}1,2,3 \\
4,5\end{array}$ & $\begin{array}{l}\text { Garnitur mebli, a mianowicie: trzy kanapy, jedna } \\
\text { sofa, sześć fotelików, dwanaście krzeseł, drzewo } \\
\text { orzechowe i wszystkie obite jutą w czerwone kwia- } \\
\text { ty na tle czekoladowego koloru - stan tych mebli } \\
\text { dobry }\end{array}$ & 120 & \\
\hline 2. & $6,7,8$ & $\begin{array}{l}\text { Kanapa i } 6 \text { krzeseł obitych perkalikiem w kwiaty, } \\
\text { drzewo politurowane, stan średni }\end{array}$ & 20 & \\
\hline 3. & 11,12 & $\begin{array}{l}\text { Kanapa i } 6 \text { krzeseł obite pąsową materią wełnianą, } \\
\text { drzewo politurowane, stan średni }\end{array}$ & 20 & \\
\hline 4. & 13,14 & $\begin{array}{l}\text { Kanapa obita perkalikiem w kwiaty (jednostajne } \\
\text { obicie z p[unktem] 2) i } 6 \text { krzeseł obite drelichem } \\
\text { w pasy, drzewo politurowane, stan średni }\end{array}$ & 15 & \\
\hline 5. & 10 & $\begin{array}{l}\text { Dwa fotele do spania, jeden obity skórą safianową, } \\
\text { do rozsuwania stary, a drugi dobry obity pąsowym } \\
\text { pluszem }\end{array}$ & $\begin{array}{l}10 \\
\text { i } 3\end{array}$ & \\
\hline 6. & 15,28 & $\begin{array}{l}\text { Szezlong obity materią w pasy, drugi szezlong } \\
\text { obity tak samo i } 2 \text { stary [sic] kanapy wybijane }\end{array}$ & 5 & \\
\hline 7. & 16 & $\begin{array}{l}\text { Trzy mahoniowe stoliki do grania, w każdym } \\
4 \text { szuflady }\end{array}$ & 3 & \\
\hline 8. & 17 & Dwa olchowe politurowane stoliki & 4 & \\
\hline 9. & - & $\begin{array}{l}\text { Kredens politurowany niski, podnoszone wieko, } \\
\text { zaś na dole dwuskrzydłowe drzwi }\end{array}$ & 5 & \\
\hline 10. & 18 & $\begin{array}{l}\text { Komoda a zarazem stół do pisania, w której } \\
3 \text { mniejszych i } 5 \text { większych szuflad z drzewa olcho- } \\
\text { wego }\end{array}$ & 5 & \\
\hline 11. & 19 & $\begin{array}{l}\text { Trzy stoły politurowane, a mianowicie: jeden duży } \\
\text { orzechowy na } 4 \text { nogach wartości } 10 \mathrm{zł} \text {, drugi orze- } \\
\text { chowy owalny na } 1 \text { nodze wartości } 6 \text { zł, trzeci zaś } \\
\text { olchowy nieduży na } 1 \text { nodze wartości } 3 \text { zł }\end{array}$ & 19 & \\
\hline 12. & 24,25 & Dwa łóżka ordynarnej roboty & & 80 \\
\hline 13. & 27 & $\begin{array}{l}\text { Duży jadalny stół prostej roboty, biało lakierowa- } \\
\text { ny }\end{array}$ & 2 & \\
\hline 14. & - & $\begin{array}{l}\text { Stół kancelaryjny a właściwie biurko z miękkiego } \\
\text { drzewa (we Lwowie) }\end{array}$ & 3 & \\
\hline 15. & 31 & Dwie politurowane spluwaczki & & 20 \\
\hline 16. & 32,38 & $\begin{array}{l}\text { Duży stół z miękkiego drzewa i stół jadalny ze } \\
\text { spuszczanymi skrzydłami }\end{array}$ & 3 & \\
\hline 17. & 33,34 & $\begin{array}{l}\text { Komoda mahoniowa o trzech szufladach i komoda } \\
\text { żółta jesionowa również o trzech szufladach }\end{array}$ & 20 & \\
\hline
\end{tabular}




\begin{tabular}{cclc}
\hline 18. & 36 & $\begin{array}{l}\text { Mała szafka na papiery z szufladami, fornirowana, } \\
\text { w bardzo złym stanie }\end{array}$ & 1 \\
\hline 19. & 39 & Szlafbank ${ }^{11}$ biało pokostowany z szufladą & 1 \\
\hline 20. & - & Stolik mahoniowy do kart & 5 \\
\hline 21. & $44,45,51$ & $\begin{array}{l}\text { Trzy łóżka, a mianowicie: jedno politurowane } \\
\text { orzechowe i 2 politurowane jesionowe, tudzież }\end{array}$ & 8 \\
& & jeden siennik & \\
\hline 22. & 48 & $\begin{array}{l}\text { Biało pokostowana szafa, a właściwie kredens na } \\
\text { stołowe naczynie }\end{array}$ & 1 \\
\hline 23. & 49 & Biało pokostowana szafa ścienna, o 2 oddziałach & 1 \\
\hline 24. & 50 & Stolik nocny, orzechowy & 3 \\
\hline 25. & 52 & Stolik olchowy politurowany z szufladą (w kaplicy) & 1 \\
\hline 26. & 54 & Zwierciadło ścienne w pozłacanych ramach & 10 \\
\hline 27. & 55 & Krucyfiks drewniany & 30 \\
\hline 28. & 56 & Dwa świeczniki pozłacane & 12 \\
\hline 29. & 20,21 & Dwa ordynarne stoły z miękkiego drzewa & 1 \\
\hline & & &
\end{tabular}

\section{Obrazy}

\begin{tabular}{|c|c|c|c|}
\hline \multicolumn{2}{|c|}{ L[iczba] bieżąca } & & \multirow{2}{*}{ A. W. } \\
\hline Nowego & Starego & & \\
\hline \multicolumn{2}{|c|}{ Inwentarza } & & zł ct. \\
\hline 1. & 61 & Portret arcybiskupa Sierakowskiego ${ }^{52}$ & 2 \\
\hline 2. & 62 & Obraz na płótnie „zdjęcie z krzyża” & 1 \\
\hline 3. & 63 & $\begin{array}{l}\text { Cztery duży [sic] obrazy przedstawiające } 4 \text { pory } \\
\text { roku }\end{array}$ & 2 \\
\hline 4. & 66 & Portret cesarza Józefa II ${ }^{53}$ w naturalnej wielkości & 10 \\
\hline
\end{tabular}

51. Z niem. Schlafbank - ławka do spania.

52. Wacław Hieronim Sierakowski (ok. 1700-1780), święcenia kapłańskie w 1726 w Krakowie, doktor obojga praw, duszpasterz i kanonik Kapituły Katedralnej w Krakowie, biskup kamieniecki 1739-1742, biskup przemyski 1742-1760, arcybiskup lwowski 1760-1780. Przeprowadził w diecezjach wizytacje, zorganizował w $1765 \mathrm{r}$. synod we Lwowie, doprowadził do renowacji katedry lwowskiej, zreformował lwowskie Seminarium Duchowne i szkolnictwo parafialne, wspierał konfederację barską. H. Borcz, Sierakowski Wacław Hieronim, w: EK, t. 18, Lublin 2013, kol. 175-176.

53. Józef II (1741-1790), syn cesarza Franciszka I Lotaryńskiego i cesarzowej Marii Teresy, cesarz rzymsko-niemiecki od 1764, cesarz-współregent od 1765, cesarz 1780-1790, zwolennik niemieckiego centralizmu i germanizacji, przeprowadził reformę Kościoła w państwie, nazywaną od jego imienia józefinizmem, z jego inspiracji Austria wzięła udział w pierwszym rozbiorze Polski w 1772 r. Szerzej: B. Kumor, Józef II, w: EK, t. 8, Lublin 2000, kol. 166-167. 


\begin{tabular}{ccll}
\hline 5. & 67 & Ośmnaście $^{56}$ portretów kanoników lwowskich & 10 \\
\hline 6. & 68 & $\begin{array}{l}\text { Portret arcybiskupa Kickiego Ferdynanda }{ }^{57} \text { w natu- } \\
\text { ralnej wielkości }\end{array}$ & 8 \\
\hline 7. & 69,70 & $\begin{array}{l}\text { Dwa portrety popiersia cesarzowej Marii Teresy }{ }^{58} \\
\text { i cesarza Józefa II }\end{array}$ & 10 \\
\hline 8. & 71 & Portret papieża Piusa VI59 & 2 \\
\hline 9. & 72 & $\begin{array}{l}\text { Trzydzieści dziewięć portretów dawniejszych arcy- } \\
\text { biskupów }\end{array}$ & 15 \\
\hline 10. & 74 & Dwa obrazki z gipsu & 50 \\
\hline 11. & 75 & $\begin{array}{l}\text { Dwa portrety a to cesarzowej Marii Teresy i cesa- } \\
\text { rza Józefa II }\end{array}$ & 5 \\
\hline 12. & 64 & Krajobraz na płótnie w pozłacanych ramach & 1 \\
\hline
\end{tabular}

54. Styl zgodny z oryginałem.

55. Ferdynand Kicki (ok. 1715-1797), do 1747 r. żołnierz armii saskiej, święcenia kapłańskie w 1750, kanclerz Kurii we Włocławku od 1754, kanonik Kapituły Katedralnej we Lwowie od 1764, proboszcz katedry w Krakowie od 1771, metropolita lwowski 1780-1797; lojalny wobec władz austriackich, biernie przyjmował kasatę klasztorów, za jego rządów rozszerzono arcybiskupstwo o nowe dekanaty. J. Warmiński, Kicki Ferdynand Onufry, w: EK, t. 8, Lublin 2000, kol. 1386-1387.

56. Maria Teresa (1717-1780), cesarzowa Austrii, królowa Czech i Węgier, panująca od 1740 r., utraciła w 1740 Śląsk na rzecz Prus, popierała konfederację barską, w 1772 uczestniczyła w I rozbiorze Polski, w polityce wewnętrznej zapoczątkowała reformy oświeconego absolutyzmu, rozbudowała administrację państwową, ograniczała polityczne wpływy Kościoła. Z. Góralski, Maria Teresa, Wrocław 1995, passim.

57. Pius VI (1717-1799), święcenia kapłańskie w 1758 r., od 1763 sekretarz papieża Benedykta XIV i kanonik bazyliki św. Piotra, skarbnik Kurii Rzymskiej, od 1773 kardynał, papież 1775-1799. Szerzej: Z. Zieliński, Pius VI, Gian Angelo Braschi, w: EK, t. 15, Lublin 2011, kol. 749-751. 
Kwiaty w cieplarni (oranżerii) w Obroszynie

\begin{tabular}{|c|c|}
\hline Gatunek & Sztuk $^{58}$ \\
\hline Adiantum capillus-veneris & 10 \\
\hline Adiantum elegans & 10 \\
\hline Adiantum frutescens & 15 \\
\hline Arum odoratum & 2 \\
\hline Aloe punitata & 1 \\
\hline Begonia cordata & 5 \\
\hline Begonia dregei & 20 \\
\hline Begonia semperflorens & 30 \\
\hline Begonia Willmottianum & 20 \\
\hline Begonia roscum & 20 \\
\hline Begonia maculata & 4 \\
\hline Begonia w różnych gatunkach & 20 \\
\hline Blechnum australis & 10 \\
\hline Blechnum species & 10 \\
\hline Cactus flagelliformis & 3 \\
\hline Cactus stellata & 2 \\
\hline Cactus spec[ies] Napoleon & 6 \\
\hline Cactus truncatus & 2 \\
\hline Cactus sexangularis & 1 \\
\hline Canna w różnych gatunkach & 100 \\
\hline Crinum americanum & 6 \\
\hline Cyperus alternifolius & 5 \\
\hline Dracaena draco & 1 \\
\hline Dracaena rosca & 10 \\
\hline Dracaena australis & 5 \\
\hline Dracaena ensifolia & 10 \\
\hline Dracaena sp[ecies] $]^{59}$ & 1 \\
\hline
\end{tabular}

58. Obok każdej sztuki, na prawym marginesie, nieznana osoba dopisała ołówkiem liczbę, która nie zawsze pokrywa się z tą uwzględnioną w wykazie. Prawdopodobnie ktoś, w bliżej nieokreślonym czasie, dokonał skontrum liczbowego hodowanych roślin. Ze względu na brak informacji na temat przyczyn i okoliczności zamieszczenia tych danych zrezygnowano z ich uwzględnienia w edytowanym dokumencie. Odnotowano jedynie dopiski słowne przy nazwach roślin.

59. Autor inwentarza nie wpisał gatunku. 
e. Obok ołówkiem dopisane słowo: "elegans".

f. Obok ołówkiem dopisana fraza: "i augustifolia 6".

g. Obok ołówkiem dopisana fraza: "Sanhesia nobilis".

h. Obok ołówkiem dopisane słowo: "bohardia".

i. Obok ołówkiem dopisane słowo: "rellinata 2 ".

\begin{tabular}{|c|c|}
\hline Eranthemum magnificum & 10 \\
\hline Eranthemum maculatum & 10 \\
\hline Eranthemum roseum & 4 \\
\hline Hoya bella & 1 \\
\hline Hoya carnea & 4 \\
\hline Euphorbia splendens & 2 \\
\hline Yucca gloriosa & 1 \\
\hline Yucca aloifolia & 2 \\
\hline Lycopodium caesium $^{\mathrm{e}}$ & 10 \\
\hline Lycopodium cordatum & 10 \\
\hline Musa cavendish & 2 \\
\hline Maranta zebrina & 1 \\
\hline Maranta media pieta & 1 \\
\hline Plumbago caerulea & 3 \\
\hline Philodendron pertusum & 1 \\
\hline Philodendron pinnatifidum ${ }^{\mathrm{f}}$ & 2 \\
\hline Piperela pieta & 2 \\
\hline Piperela grasifolia & 1 \\
\hline Pteris lineata & 10 \\
\hline Pteris lineata alba & 3 \\
\hline Senecio Buplandig & 2 \\
\hline Urtica macrophylla $^{\mathrm{h}}$ & 5 \\
\hline Rochea falcata & 5 \\
\hline \multicolumn{2}{|l|}{ Palmy } \\
\hline Latania borbonica & 4 \\
\hline Corypha australis & 1 \\
\hline Chamaerops humilis & 1 \\
\hline Phoenix dactylifera $^{\mathrm{i}}$ & 1 \\
\hline Gloxinen & 5 \\
\hline Gesnerien & 5 \\
\hline Neugelien & 5 \\
\hline Achimenes & 5 \\
\hline Gladiolus & 5 \\
\hline \multicolumn{2}{|l|}{ Rośliny oranżeryjne } \\
\hline Abutilon striatum & 25 \\
\hline Abutilon venosum & 5 \\
\hline Abutilon Thomsonii & 5 \\
\hline Abutilon species & 5 \\
\hline
\end{tabular}




\begin{tabular}{|c|c|}
\hline Azalea indica & 10 \\
\hline Agapanthus umbellatus & 20 \\
\hline Agapanthus umbellatus alba striata & 3 \\
\hline Agarathum glancum & 10 \\
\hline Agarathum species & 2 \\
\hline Agave americana & 6 \\
\hline Agave americana striata & 2 \\
\hline Acacia lophantha & 6 \\
\hline Acacia verticillata & 6 \\
\hline Acacia amara & 1 \\
\hline Camellia japonica & 10 \\
\hline Correa alba & 2 \\
\hline Cunnighamia lanceolata & 3 \\
\hline Cuphea platycentra & 100 \\
\hline Cestrum & 3 \\
\hline Cupressus sempervirens & 25 \\
\hline Callistemon semperflorens & 10 \\
\hline Callistemon angustifolium & 10 \\
\hline Daphne odora & 1 \\
\hline Elaeagnus angustifolia & 3 \\
\hline Eucalyptus ${ }^{\mathrm{j}}$ & 1 \\
\hline Escallonia rosea & 2 \\
\hline Eugenia australis & 30 \\
\hline Euonymus viridis & 50 \\
\hline Euonymus folveriegatis $^{\mathrm{k}}$ & 40 \\
\hline Euonymus auvia variegatis & 3 \\
\hline Fuchsia w różnych gatunkach & 50 \\
\hline Fuchsia fulgens & 3 \\
\hline Fuchsia corymbiflora rosca & 5 \\
\hline Fuchsia arborea & 5 \\
\hline Phormium tenax & 2 \\
\hline Habrothamus speciosus & 10 \\
\hline Habrothamus Hygeli & 2 \\
\hline Hydrangea japonica & 4 \\
\hline Hydrangea hortensis & 100 \\
\hline Hydrangea folvariaegatis & 4 \\
\hline Heliotropium w różnych gatunkach & 40 \\
\hline Justicia arborea & 14 \\
\hline
\end{tabular}

j. Obok ołówkiem dopisane słowo: "globulus".

k. Obok ołówkiem dopisane słowo: "raticans". 
1. Obok ołówkiem dopisane słowo: "tigrinum".

m. Obok ołówkiem dopisane słowo: "coralinum".

n. Obok ołówkiem dopisane słowo: "nigrescens".

o. Obok ołówkiem dopisana fraza: "-300, sztamowych $40 "$.

\begin{tabular}{|c|c|}
\hline Jasminum sambac & 4 \\
\hline Jasminum odoratum & 15 \\
\hline Laurus camphora ${ }^{1}$ & 1 \\
\hline Laurus nobilis & 1 \\
\hline Libonia & 10 \\
\hline Lonicera & 100 \\
\hline Nerium splendens & 10 \\
\hline Melaleuca ericoida & 10 \\
\hline Melaleuca alba & 10 \\
\hline Metrosideros robusta & 2 \\
\hline Myrtus & 50 \\
\hline Myrtus latifolia & 3 \\
\hline Passiflora caerulea & 1 \\
\hline Polygonum sp. & 4 \\
\hline Podocarpus pungens & 6 \\
\hline Podocarpus lincata & 2 \\
\hline Punica granatum & 3 \\
\hline Prunus laurocerasus & 30 \\
\hline Pelargonium englische & 20 \\
\hline Pelargonium zonale w gatunkach & 200 \\
\hline Pittosporum tobira & 5 \\
\hline Rhus lanceolata & 10 \\
\hline Rhus obovata & 10 \\
\hline Rhododendron ponticum & 15 \\
\hline Santolina & 30 \\
\hline Salvia lanata & 3 \\
\hline Salvia splendens & 3 \\
\hline Solanum lycoporsicum ${ }^{\mathrm{m}}$ & 3 \\
\hline Thuja w gatunkach & 10 \\
\hline Tecoma jasminoides & 10 \\
\hline${\text { Vinca } \text { major }^{\mathrm{n}}}$ & 6 \\
\hline Viburnum tinus & 6 \\
\hline Wellingtonia gigantea & 1 \\
\hline Róże miesięczne ${ }^{\circ}$ & 100 \\
\hline Gwoździki [sic] w gatunkach & 100 \\
\hline Georginie & 100 \\
\hline Chrysanthemum & 50 \\
\hline
\end{tabular}


Rośliny dywanowe ${ }^{60}$

Alternanthera w gatunkach

\begin{tabular}{|c|c|}
\hline \multicolumn{2}{|l|}{ Centaurea argentea w gatunkach } \\
\hline \multicolumn{2}{|l|}{ Echeveria w gatunkach } \\
\hline \multicolumn{2}{|l|}{ Irisine w gatunkach } \\
\hline \multicolumn{2}{|l|}{ Gnaphalium lanatum } \\
\hline \multicolumn{2}{|l|}{ Lobelia } \\
\hline \multicolumn{2}{|l|}{ Lonicera brachypoda } \\
\hline \multicolumn{2}{|l|}{ Thymus citrodorus } \\
\hline \multicolumn{2}{|l|}{ Coleus w gatunkach } \\
\hline \multicolumn{2}{|l|}{ Drzewa cytrynowe i figowe } \\
\hline Drzew cytrynowych dużych & 12 \\
\hline Drzew cytrynowych małych & 20 \\
\hline Drzew figowych dużych & 6 \\
\hline Drzew figowych małych & 12 \\
\hline \multicolumn{2}{|l|}{ Drzewa owocowe } \\
\hline Jabłonie i grusze stare & 419 \\
\hline Jabłonie i grusze młode & 247 \\
\hline Śliwki i wiśnie stare i młode & 599 \\
\hline Brzoskwinie drzew & 10 \\
\hline Morele (aprikoty) & 4 \\
\hline Ryngloty ${ }^{61}$ & 30 \\
\hline Winogrona szczepów & 30 \\
\hline \multicolumn{2}{|l|}{ Ananasy } \\
\hline Ananasów owocowych & 15 \\
\hline Ananasów dwuletnich & 64 \\
\hline Ananasów jednorocznych & 50 \\
\hline
\end{tabular}

6o. Nie podano liczby sztuk, ani bliższych danych ilościowych.„-300, sztamowych 40".

61. Zapis zgodny z oryginałem. Mowa o renklodach - odmianie śliwy. 
p. Obok ołówkiem Narzędzia i sprzęty ogrodowe dopisana fraza: "67 ramy 4".

\begin{tabular}{|c|c|}
\hline [Opis] & Sztuk $^{62}$ \\
\hline Okien inspektowych ${ }^{p}$ & 80 \\
\hline Rafa druciana & 1 \\
\hline Taczki czyli graca do czyszczenia dróg & 1 \\
\hline Nosze & 2 \\
\hline Wózek ręczny do wywożenia wazonów & 1 \\
\hline Taczki & 1 \\
\hline Nożyc do obcinania drzew & 2 \\
\hline Piłka ogrodowa & 2 \\
\hline Piłka ręczna & 1 \\
\hline Łopat żelaznych & 3 \\
\hline Grabie żelazne & 1 \\
\hline Kadź na wodę żelaznymi obręczami obita & 1 \\
\hline Konewek blaszanych do podlewania & 4 \\
\hline Wideł żelaznych & 3 \\
\hline Kanap drewnianych & 20 \\
\hline Krzeseł plecionych z pręcia & 6 \\
\hline Kanapa pleciona z pręcia & 1 \\
\hline Kanapa z korzeni drzewnych & 1 \\
\hline Krzeseł z korzeni drzewnych & 2 \\
\hline Stół z korzeni drzewnych & 1 \\
\hline Kłódek & 4 \\
\hline
\end{tabular}

62. Obok każdej sztuki wykazu, na prawym marginesie, nieznana osoba dopisała ołówkiem liczbę, która nie zawsze pokrywa się z tą uwzględnioną w wykazie. Prawdopodobnie ktoś, w bliżej nieokreślonym czasie, dokonał skontrum liczbowego narzędzi i sprzętów. Ze względu na brak informacji na temat przyczyn i okoliczności zamieszczenia tych danych, zrezygnowano z ich uwzględnienia w edytowanym dokumencie. 
Sprzęty i aparaty kościelne, sprzęty pokojowe, obrazy, narzędzia ogrodowe i kwiaty odebrałem.

Obroszyn, 9 lipca 1885

Ks. Andrzej Mazurak Jako oddający

Wobec c. k. Komisji:

Leopold Szabel

c.k. radca Namiestnictwa
Romuald Morawski Pełnomocnik J[aśnie] W[ielmożnego] Ks. arcybiskupa łac. Jako odbierający Mieczysław Komarnicki c.k. oficjał rach[unkowy] Namiestnictwa 


\section{Inwentarz z 1900 roku (?) z aktualizacjami z 1923 roku}

q. Obok, na marginesie, widnieja dwie późniejsze informacje.

Pierwsza obcą ręką: "Na folwarku w Obroszynie wybudowano stajnię i chlewy murowane, tudzież szopę kosztem 15640 [koron]. Zob. ad poz. 16"; druga - ręka ks. Demitrowskiego: „L. Nam. 84088/1902. W majętn[ości] tab[ularnej] Obroszyn z parceli grunt[owej] L.k. 772 sprzedano pod kolej Lwów - Sambor - granica węgierska 2 morgi i 106 sążni [kwadratowych] za 3107 k[oron] 64 h[alerze]".

Majętność tabularna, oddalona $11 \mathrm{~km}$ od Lwowa, położona przy drodze krajowej Zimno-woda ${ }^{63}$ - Hoszany. Od drogi tej skręca się w lewo koło figury św. Dominika na drogę prywatną wysadzaną lipami, która wiedzie do pałacu arcybiskupiego, położonego w obszernym parku. Przed pałacem leży obszerne podwórze z gazonem, pośrodku okolone częścią budynkami, częścią zaś murem, w którym 3 wielkie bramy sztachetowe ${ }^{q}$.

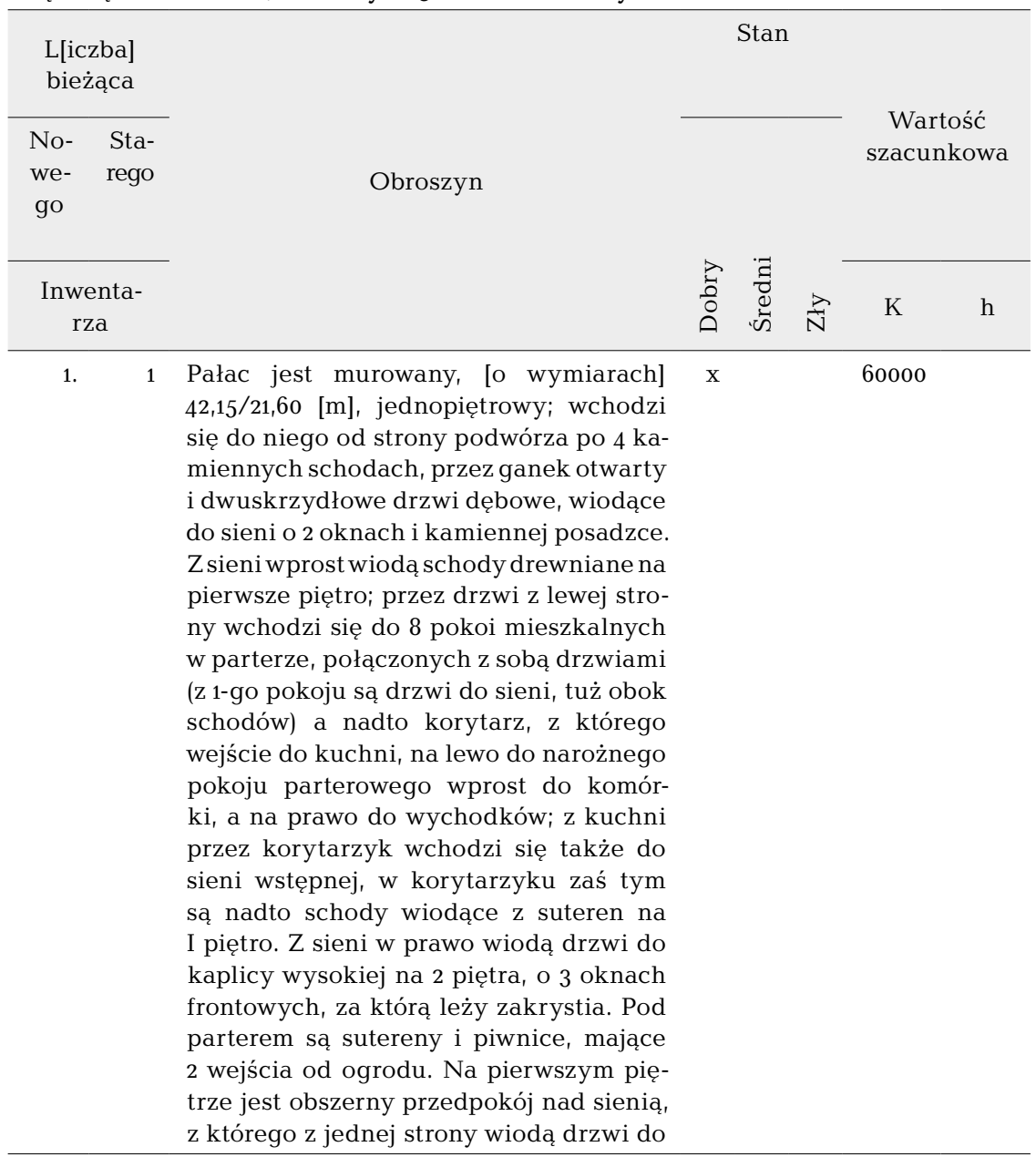

63. Właśc.: Zimna Woda - wieś w pow. Lwów, woj. lwowskie. 


\begin{tabular}{|c|c|c|c|}
\hline & $\begin{array}{l}\text { loggii w kaplicy, po drugiej zaś stronie do } \\
4 \text { pokoi mieszkalnych i dużej sali. Z sali } \\
\text { prowadzi korytarz o } 2 \text { oknach do poko- } \\
\text { ju narożnego; w prawo z tego korytarza } \\
\text { przez korytarzyk ciemny wchodzi się do } \\
\text { wychodków, tudzież do małego pokoju. } \\
\text { Do korytarza tego wiodą schodki małe do } \\
\text { I piętra, a z niego schodki na strych. We } \\
\text { wszystkich pokojach są piece ogrzewal- } \\
\text { ne, dawnej konstrukcji, niektóre ozdobne, } \\
\text { okna 4-skrzydłowe podwójne, równie jak } \\
\text { drzwi, biało lakierowane, ściany malo- } \\
\text { wane, a podłogi z miękkich desek na fry- } \\
\text { zach; dach blaszany. Stan budynku zre- } \\
\text { staurowanego przed } 4 \text { laty kosztem } 28 \text { ooo } \\
\text { zł zupełnie dobry4 }\end{array}$ & & \\
\hline 2. & $\begin{array}{l}\text { Po prawej stronie podwórza, patrząc od } \\
\text { strony pałacu, stoi spichlerz murowany } \\
\text { [o wymiarach] } 22,80 / 9[\mathrm{~m}] \text { gontem kryty }\end{array}$ & & \multirow{2}{*}{2000} \\
\hline 3. & $\begin{array}{l}\text { Dalej wozownia sklepiona [o wymiarach] } \\
7,80 / 7,80[\mathrm{~m}] \text { gontem kryta z 2-ma drewut- } \\
\text { niami }^{t}\end{array}$ & & \\
\hline 4. & $\begin{array}{l}\text { Dom mieszkalny [o wymiarach] } 15,50 / 5,80 \\
\text { [m] złożony z sieni, pokoju, kuchni i } 2 \text { spi- } \\
\text { żarni }^{u}\end{array}$ & $\mathrm{x}$ & 1000 \\
\hline 5. & $\begin{array}{l}\text { Wieżyczka, w której dawniej był zegar } \\
\text { (zardzewiały, złożony w magazynie), } \\
\text { wreszcie główna brama wjazdowav }\end{array}$ & & 50 \\
\hline
\end{tabular}

r. Na marginesie opisu pałacu widnieje adnotacja ręką ks. Demitrowskiego: „ad. 1. Pałac wskutek kwaterunków, pomieszczenia szpitala 15 korpusu tureckiego, wspierającego armię austriacką w działaniach wojennych przeciw Rosji i wskutek działań wojennych w roku 1918/9 zniszczony. Restaurację pałacu rozpoczęto w r. 1922 pod fachowym kierownictwem inżynierów Wiktora \& Blady przy współudziale [bezpośrednio po tym słowie widniała tutaj fraza: „departamentu oddziału kultury i sztuki Województwa pod kierownictwem dr. Piotrowskiego" - wykreślona przez ks. Demitrowskiego] rządowego konserwatora dr. Piotrowskiego, kierownika oddziału kultury i sztuki przy Województwie lwowskim. Opis szczegółowy pałacu pomieści się w inwentarzu po ukończeniu restauracji".

s. Na marginesie adnotacja ręką ks. Demitrowskiego: „ad. 2. Stan budynku wymaga gruntownej restauracji [bezpośrednio po tym słowie widniała tutaj fraza: „i przywrócenia" - wykreślona przez ks. Demitrowskiego].

t. Na marginesie adnotacja ręką ks. Demitrowskiego: „ad. 3. Wozownię (basztę) odrestaurowano i pokryto blachą w r. 1916".

u. Na marginesie adnotacja ręką ks. Demitrowskiego: "ad. 4. Restauracja domu w toku". 


\begin{tabular}{|c|c|c|c|c|c|}
\hline 6. & & $\begin{array}{l}\text { Po drugiej stronie bramy wjazdowej } \\
\text { w półkolu ku pałacowi stoi druga wie- } \\
\text { życzka bez przeznaczeniaw }^{w}\end{array}$ & & & 50 \\
\hline 7. & & $\begin{array}{l}\text { Obok niej dom mieszkalny [o wymiarach] } \\
15,50 / 5,80 \text { [m] zajęty przez służbę dzier- } \\
\text { żawcy i mający wyjście na dziedziniec } \\
\text { folwarczny }\end{array}$ & & & 2000 \\
\hline 8. & & $\begin{array}{l}\text { Obok tego domu druga wozownia [o wy- } \\
\text { miarach] } 7,80 / 7,80[\mathrm{~m}]^{\mathrm{y}}\end{array}$ & & & 1000 \\
\hline 9. & & $\begin{array}{l}\text { Poza nią zaś dom mieszkalny [o wymia- } \\
\text { rach] 24,20/10,20 [m], do którego od strony } \\
\text { podwórza wchodzi się przez drzwi z sion- } \\
\text { ką, z której wejście do } 2 \text { z sobą połączo- } \\
\text { nych pokoi. Z drugiej strony sieni są rów- } \\
\text { nież } 2 \text { pokoje, a naprzeciw nich po drugiej } \\
\text { stronie budynku takież same } 2 \text { pokoje } \\
\text { z wyjściem do sieni przedzielonej na } 2 \text { po- } \\
\text { łowy i mającej drzwi do wielkiej kuchni } \\
\text { bez podłogi, a ponadto przez werandę na } \\
\text { podwórze gospodarcze. Wszystkie te bu- } \\
\text { dynki [wymienione pod poz. } 2-9-\text { GCh] } \\
\text { są murowane, gontem kryte, w stanie } \\
\text { średnimz }\end{array}$ & $\mathrm{x}$ & & 2000 \\
\hline 10. & 2 & $\begin{array}{l}\text { Murowany budynek, używany przez } \\
\text { ogrodnika i jego pomocników jako miesz- } \\
\text { kanie [o wymiarach] 45/12,80 [m]; do bu- } \\
\text { dynku tego przypiera od strony ogrodu } \\
\text { wielka oranżeria. Część oranżerii od stro- } \\
\text { ny pałacu jest zawalona; odpowiednia } \\
\text { część budynku mieszkalnego wali się. Do } \\
\text { budynku tego wchodzi się przez oszklony } \\
\text { ganek do sionki; z niej w prawo do kuch- } \\
\text { ni, w lewo zaś do } 2 \text { pokoi mieszkalnych. } \\
\text { Wprost sionki wchodzi się do oranżeriiaa }\end{array}$ & & $\mathrm{x}$ & 2000 \\
\hline
\end{tabular}

v. Na marginesie adnotacja ręką ks. Demitrowskiego: "ad. 5. Zniszczona wskutek działań wojennych w 1919 [r.] i restauracja w toku. Brama wjazdowa zniszczona".

w. Na marginesie adnotacja ręką ks. Demitrowskiego: „ad. 6. Restauracja w toku".

x. Na marginesie adnotacja ręką ks. Demitrowskiego: „ad. 7. Restauracja w toku".

y. Na marginesie adnotacja ręką ks. Demitrowskiego: „ad. 8. Restauracja w toku".

z. Na marginesie adnotacja ręką ks. Demitrowskiego: „ad. 9. "Dom dzierżawcy” obecnie mieszkanie dyrektora dóbr; zniszczony wskutek działań wojennych, odrestaurowano: dach (gonty), podłogi, okna, drzwi, piece, wyprawiono ściany, dalsza restauracja w toku".

aa. Na marginesie adnotacja ręką ks. Demitrowskiego: „ad. 10. Wielka oranżeria zniszczona wskutek działań wojennych w r. 1914, odbudowano w lecie r. 1915, zniszczona ponownie w lutym 1919 r.; dom mieszkalny ogrodnika zniszczony w lutym 


\begin{tabular}{|c|c|c|c|c|}
\hline 11. & & $\begin{array}{l}\text { W ogrodzie stoi cieplarnia [o wymiarach] } \\
\text { 15/4 [m], a obok niej inspekta, tudzież lo- } \\
\text { downia }^{\text {ab }}\end{array}$ & $x$ & 600 \\
\hline 12. & & $\begin{array}{l}\text { Ogród jest otoczony parkanem, w dalszej } \\
\text { zaś części ogrodzony płotem. Po drugiej } \\
\text { stronie pałacu przez bramę wchodzi się } \\
\text { na podwórze gospodarcze, na którym sto- } \\
\text { ją następujące budynkiac: }\end{array}$ & & \\
\hline 13 & 4 & $\begin{array}{l}\text { Stajnia [o wymiarach] 57/9,90 [m], w któ- } \\
\text { rej od strony pałacu dobudowana jest } \\
\text { część mieszkalna, składająca się z sionki } \\
\text { i } 3 \text { pokoi, z których } 2 \text { połączone, a } 1 \text { z osob- } \\
\text { nym wchodem. Z tej samej sionki w prawo } \\
\text { wchodzi się do stajni ze żłobami i drabi- } \\
\text { nami. W środku prowadzi wchód także do } \\
\text { stajni; trzeci zaś wchód po prawej stronie } \\
\text { do wozowni, którą przedzielono i w poło- } \\
\text { wie otworzono stajnię dla jałownika. } \\
\text { Budynek ten jest murowany, ściany jed- } \\
\text { nak u dołu z tynku obdarte, dach gontem } \\
\text { kryty, w części nad wozownią jednak } \\
\text { zniszczony; w wozowni nie ma powały, } \\
\text { w innych zaś częściach [jest] powała } \\
\text { z desek. Nieopodal tego budynku stoi } \\
\text { brama wjazdowa między dębowymi słu- } \\
\text { pami, przypierającymi do białych filarów, } \\
\text { która zamyka podwórze gospodarcze, } \\
\text { okolone parkanem ze stojących desek. }\end{array}$ & & 3500 \\
\hline 14. & 6 & $\begin{array}{l}\text { Niedaleko bramy jest studnia ocembro- } \\
\text { wana z wałem i wiadrami }{ }^{\text {ad }}\end{array}$ & $x$ & 100 \\
\hline 15 & 7 & $\begin{array}{l}\text { Poza nią lodownia pod słomianym da- } \\
\text { chem [o wymiarach] } 15,10 / 5[\mathrm{~m}]^{\text {ae }}\end{array}$ & $\mathrm{x}$ & 50 \\
\hline 16. & 8 & $\begin{array}{l}\text { Naprzeciw stajni, powyżej opisanej, stoi } \\
\text { murowana krowiarnia pod dachem gon- } \\
\text { towym złym. Do stajni prowadzi dwoje }\end{array}$ & & 2000 \\
\hline
\end{tabular}

r. 1919, przy czym ogrodnik Nowotny i jego 2 dorosłe córki zginęli równocześnie wskutek eksplozji granatu na ganku. Odbudowa w toku".

ab. Na marginesie adnotacja ręką ks. Demitrowskiego: „ad. 1. Cieplarnia zniszczona w 1914 [r.], odbudowana w r. 1915. Powtórnie zniszczona w 1919 [r.]. Odbudowę rozpoczęto w r. 1922".

ac. Na marginesie adnotacja ręką ks. Demitrowskiego: „ad. 12. Parkan i płot uległy zniszczeniu w ciągu działań woj[ennych] od 1914-1919. Parkan nowy wokoło całego ogrodu (parku) na słupach dębowych postawiono w r. 1922 i zaopatrzono 4 rzędami drutu kolczastego górą na hakach żelaznych. Deski umocowano 2 rzędami taśmy żelaznej (walcówki)".

ad. Na marginesie adnotacja ręką ks. Demitrowskiego: „ad. 14. Studnię zaopatrzono w przyrząd pompowy ok. r. 1906". 


\begin{tabular}{|c|c|c|c|c|}
\hline & & $\begin{array}{l}\text { drzwi: filar przyczółkowy od strony obory } \\
\text { usuwa się i wymaga naprawy, powała zła, } \\
\text { [wymiary] 26,50/8,70 [m] }]^{\text {af }}\end{array}$ & & \\
\hline 17. & 9 & $\begin{array}{l}\text { Dalej stoi stodoła murowana pod dachem } \\
\text { gontowym, mająca dwoje wrót dwuskrzy- } \\
\text { dłowych i dwoje drzwi. Do stodoły przy- } \\
\text { tyka kierat o dębowych słupach i plecio- } \\
\text { nych z chrustu ścianach. Dach wymaga } \\
\text { naprawy; [wymiary] 26,3/9 [m] }]^{\text {ag }}\end{array}$ & & - \\
\hline 18. & 11 & $\begin{array}{l}\text { Niedaleko stodoły stoi szopa otwarta pod } \\
\text { gontowym dachem spoczywającym na } \\
33 \text { słupach dębowych spodem zgnitych; } \\
\text { [wymiary] } 36 / 10,50[\mathrm{~m}]^{\text {ah }}\end{array}$ & $\mathrm{x}$ & 2000 \\
\hline 19. & 13 & $\begin{array}{l}\text { Przy drodze do Basiówki, tuż przy ogro- } \\
\text { dzie pałacowym, stoi dom murowany pod } \\
\text { dachem gontowym. Budynek ma } 6 \text { okien } \\
\text { z okiennicami i } 2 \text { osobne wchody. W środ- } \\
\text { ku budynku wchodzi się do sieni, a z niej } \\
\text { do izby szynkowej, z której wchód do piw- } \\
\text { nicy. Z sieni na lewo wchodzi się do przed- } \\
\text { pokoju, z którego w prawo do komórki, } \\
\text { wprost zaś do } 2 \text { pokoi, poza którymi } 2 \text { ma- } \\
\text { gazyny. W jednym z tych pokoi jest pod- } \\
\text { łoga z desek, winnym zaś z cegieł. Wprost } \\
\text { z sieni wchodzi się do komórki, z której } \\
\text { schody na strych; [wymiary] 28,10/8 [m] }{ }^{\mathrm{ai}}\end{array}$ & & - \\
\hline 20. & & $\begin{array}{l}\text { Obok domu stodoła na podwalinach i słu- } \\
\text { pach dębowych, ściany z desek miękkich, } \\
\text { gontami pobita, bez powały; wewnątrz } \\
2 \text { zasieki; w ścianie bocznej od strony } \\
\text { domu brama wjazdowa 2-skrzydłowa, }\end{array}$ & & - \\
\hline
\end{tabular}

ae. Na marginesie adnotacja ręką ks. Demitrowskiego: „ad. 15. Lodownię przeniesiono w bezpośrednie sąsiedztwo baszty prawej, patrząc do pałacu".

af. Na marginesie adnotacja ręką ks. Demitrowskiego: „ad. 16. W miejsce starej krowiarnii wybudowano w r. 1906 nową, murowaną o wymiarach 41,25 m × 8,80 m. Budynek ten został zniszczony wskutek działań wojennych w r. 1919. Odbudowany prawie od fundamentów w r. 1922".

ag. Na marginesie adnotacja ręką ks. Demitrowskiego: "ad. 17. Zniszczona wskutek działań wojennych w r. 1919. Na tym samym miejscu wybudowano nową stodołę drewnianą $30 \mathrm{~m} \times$ 9,20 $\mathrm{m}$ - do szczytu dachu $9 \mathrm{~m}$, w r. 1922/3".

ah. Na marginesie adnotacja ręką ks. Demitrowskiego: „ad. 18. Szopa uległa zniszczeniu w r. 1916 i 1918/19". 
w drugiej zaś ścianie przyczółkowej

drzwi jednoskrzydłowe ${ }^{\text {aj }}$

\section{Sprzęty i aparaty kościelne w kaplicy ${ }^{\text {ah }}$}

\begin{tabular}{|c|c|c|}
\hline \multicolumn{2}{|c|}{ L[iczba] bieżąca } & \multirow{3}{*}{ [Wyposażenie kaplicy] } \\
\hline Nowego & Starego & \\
\hline \multicolumn{2}{|c|}{ Inwentarza } & \\
\hline 1. & 1. & $\begin{array}{l}\text { Wielki ołtarz z gipsowej mozaiki, a w nim wielki krucyfiks } \\
\text { drewniany, dwie białe figury aniołów }\end{array}$ \\
\hline 2. & 2. & Dwa boczne ołtarze z gipsowej mozaiki \\
\hline 3. & 3. & $\begin{array}{l}\text { Ornat biały atłasowy haftowany jedwabiem ze złotymi borta- } \\
\text { mi, zupełnie zniszczony }\end{array}$ \\
\hline 4. & 4. & 5 stuł zniszczonych \\
\hline 5. & 7. & $\begin{array}{l}\text { Dzwonek na ścianie przy wchodzie do zakrystii zupełnie } \\
\text { zniszczony }\end{array}$ \\
\hline 6. & 8. & Klęcznik drewniany \\
\hline 7. & 9. & Konfesjonał drewniany pokostowany \\
\hline 8. & 10. & Fotel z pultem \\
\hline 9. & 11. & 2 lawki pokostowane \\
\hline 10. & 12. & 4 poduszki włóczkowe stoczone przez mole \\
\hline 11. & 15. & Faldistorium z nakryciem jedwabnym \\
\hline 12. & 16. & Postument drewniany z cynową miednicą \\
\hline 13. & 17. & 2 relikwiarzyki mosiężne \\
\hline 14. & 18. & 6 lichtarzy cynowych \\
\hline 15 . & 19. & Kropielnica alabastrowa \\
\hline 16. & 20. & Komoda z 3-ma szufladami zużyta \\
\hline
\end{tabular}

ai. Na marginesie adnotacja ręką ks. Demitrowskiego: „ad. 19. Dom używany na pomieszczenie służby folwarcznej, zniszczony w r. 1918/19, odbudowany w r. 1922/3".

aj. Na marginesie adnotacja ręką ks. Demitrowskiego: „ad. 20. Zniszczona w r. 1918/19 wskutek działań wojennych. Na jej miejscu wybudowano nową szopę z dachem jednospadkowym w [r.] 1922/3". Ponadto ks. Demitrowski zanotował: „Przybytki budowlane: 1) Chlewy, wybudowane w r. 1906, zniszczone w r. 1918/19, odbudowane w r. 1922/3; 2) Szopa drewniana z dachem gontowym jednospadkowym przytykająca pod prostym kątem do stajni, opisanej pod nr 13, wybudowana w r. 1921/22; 3) Studnia pompowa, $18 \mathrm{~m}$ głęboka (przy tzw. czworaku - zob. nr 19), wywiercona w r. 1923; 4) Studnia przy oranżerii pompowa w r. 1905, zniszczona w r. 1918/19, odbudowana w r. 1922; 5) Basen betonowy na wodę przy oranżerii - wybudowany w r. 1916, zniszczony w r. 1918/19, odbudowany w r. 1923; 6) «Żandarmeria», dom murowany, blachą kryty, o 6 pokojach i kuchni wybudowany w r. 1905 na miejscu rozebranej w r. 1893 jednopiętrowej tzw. mandatarii, czyli mieszkania zarządcy - zob. inwentarz spisany w r. 1884/5 «ad. 12»; 7) Parkan - zob. «ad. 12»". 


\begin{tabular}{|c|c|c|}
\hline 17. & & 6 lichtarzy drewnianych pozłacanych \\
\hline 18. & & 2 lichtarze drewniane posrebrzane \\
\hline 19. & & 2 fotele stare \\
\hline 20. & & 1 spluwaczka \\
\hline 21. & & 1 zwykły stolik \\
\hline 22. & & 1 krucyfiks ścienny \\
\hline 23. & & 1 klęcznik stary \\
\hline \multirow[t]{2}{*}{24.} & & Schodki o 3 stopniach \\
\hline & & Obrazy w kaplicy \\
\hline 25 . & & $\begin{array}{l}12 \text { obrazów przedstawiających Apostołów bardzo zniszczo- } \\
\text { nych (1 bez ramy) }\end{array}$ \\
\hline 26. & & Obraz św. Jana Nepomucena ${ }^{82}$ w pozłacanych ramach \\
\hline 27. & 22. & Obraz św. Bernarda \\
\hline 28. & 23. & Obraz św. Marii Magdaleny \\
\hline 29. & 24. & Dzieciątko Jezus z wosku \\
\hline 30. & 25 . & Wizerunek Zbawiciela na krzyżu \\
\hline 31. & 25 . & Wizerunek Marii Magdaleny \\
\hline 32. & 26. & Obraz Matki Boskiej \\
\hline 33. & 27. & Wizerunek Zbawiciela z wosku \\
\hline 34. & 28. & Wizerunek Matki Boskiej z Dzieciątkiem. Jezus zniszczony \\
\hline 35. & 29. & Wizerunek Zbawiciela \\
\hline 36. & & $\begin{array}{l}\text { Zdjęcie z krzyża i ucieczka do Egiptu (odlew gipsowy w ra- } \\
\text { mach) }\end{array}$ \\
\hline \multirow[t]{2}{*}{37.} & & 7 obrazów zupełnie zniszczonych \\
\hline & & Księgi liturgiczne \\
\hline 38. & 30. & Missale Romanum \\
\hline 39. & 31. & Ceremoniale Episcoporum (2 egz.) \\
\hline 40. & 32. & Canon Missae Pontificalis \\
\hline 41. & 33. & Thesaurus sacrorum rituum \\
\hline 42. & 34. & Martyrologium \\
\hline 43. & 35. & Ritualis altera pars (zniszczony) \\
\hline
\end{tabular}

64. Jan Nepomucen (ok. 1350-1393), święty kościoła katolickiego, męczennik, utopiony w Wełtawie, patron dobrej sławy, żeglarzy, flisaków i budowniczych mostów. Szerzej: K. Kuźmak, Jan Nepomucen, w: EK, t. 7, Lublin 1997, kol. 812-814. 
Sprzęty w pałacu ${ }^{\mathrm{al}}$

\begin{tabular}{|c|c|c|c|c|c|}
\hline \multicolumn{2}{|c|}{ L[iczba] bieżąca } & & \multicolumn{3}{|c|}{ Stan } \\
\hline Nowego & Starego & & \multirow{3}{*}{$\begin{array}{l}\stackrel{\imath}{0} \\
0 \\
0\end{array}$} & \multirow{3}{*}{ ఫే } & \multirow{3}{*}{ ते } \\
\hline \multicolumn{2}{|c|}{ Inwentarza } & & & & \\
\hline 1. & 1. & $\begin{array}{l}2 \text { kanapy, sofa, } 6 \text { foteli, } 3 \text { krzesła z drzewa orze- } \\
\text { chowego kryte jutą }\end{array}$ & & & \\
\hline 2. & 2. & Szezlong kryty drelichem & & & $\mathrm{x}$ \\
\hline 3. & & Stół do kart orzechowy & & & $\mathrm{x}$ \\
\hline 4. & & 2 stoły orzechowe & & & $\mathrm{x}$ \\
\hline 5 . & & Kanapa i 6 krzeseł obitych rypsem i drelichem & & & $\mathrm{x}$ \\
\hline 6. & & $\begin{array}{l}\text { Kanapa, } 2 \text { fotele, } 8 \text { krzeseł, obitych satynąam } \\
\text { w kwiaty }\end{array}$ & & & $\mathrm{x}$ \\
\hline 7. & & 2 stoły okrągłe orzechowe & & & $\mathrm{x}$ \\
\hline 8. & & Lustro weneckie w ramach złoconych & $\mathrm{x}$ & & \\
\hline 9. & & 2 kanapy, kryte kretonem w kwiaty & & & $\mathrm{x}$ \\
\hline 10. & & Łóżko orzechowe & & & $\mathrm{x}$ \\
\hline 11. & & Stolik nocny olchowy & & & $\mathrm{x}$ \\
\hline 12. & & $\begin{array}{l}\text { Kanapa mahoniowa }{ }^{\text {an }} \text { o } 3 \text { szufladach z hanheba- } \\
\text { mi }^{65}-\text { stara }\end{array}$ & & & $\mathrm{x}$ \\
\hline 13. & & Wielki fotel ceratowy & & & $\mathrm{x}$ \\
\hline 14. & & Stół jadalny & & & $\mathrm{x}$ \\
\hline 15 . & & Kanapka i 6 krzeseł & & & $\mathrm{x}$ \\
\hline 16. & & Kredens stary olchowy & & & $\mathrm{x}$ \\
\hline 17. & & Komoda jasionowa o 3 szufladach & & & $\mathrm{x}$ \\
\hline 18. & & 2 stoliki & & & $\mathrm{x}$ \\
\hline 19. & & 2 kanapki całkiem zniszczone & & & $\mathrm{x}$ \\
\hline 20. & & Stare biurko w kształcie komody & & & $\mathrm{x}$ \\
\hline 21. & & Stół & & & $\mathrm{x}$ \\
\hline 22. & & Fotel biały obity drelichem & & & $\mathrm{x}$ \\
\hline
\end{tabular}

ak. Na marginesie, przy każdej pozycji z tej grupy, ks. Demitrowski zanotował: „Zniszczony w czasie działań wojennych w r. 1918/19".

al. Na marginesie, przy całej tej grupie, ks. Demitrowski zanotował: "Zniszczone w czasie działań wojennych w r. 1914-1919".

am. Bezpośrednio przed tym wyrazem widniało słowo: "drelichem" - wykreślone przez autora inwentarza.

an. Bezpośrednio przed tym wyrazem widniało słowo: „orzechowa" - wykreślone przez autora inwentarza.

65. Zapis zgodny z oryginałem. Być może autor inwentarza miał tutaj na myśli niemieckie słowo handhebel - dźwignia ręczna. 


\begin{tabular}{clc}
\hline 23. & Fotel stary obity pluszem wyzłacany & $\mathrm{x}$ \\
\hline 24. & Szezlong zniszczony & $\mathrm{x}$ \\
\hline 25. & Stół prosty zniszczony & $\mathrm{x}$ \\
\hline 26. & 3 stoły kredensowe & $\mathrm{x}$ \\
\hline
\end{tabular}

\section{Obrazy $^{\mathrm{ao}}$}

\begin{tabular}{|c|c|c|}
\hline \multicolumn{2}{|c|}{ L[iczba] bieżąca } & \\
\hline Nowego & Starego & \\
\hline \multicolumn{2}{|c|}{ Inwentarza } & \\
\hline 27. & 1. & Portret arcybiskupa Sierakowskiego \\
\hline 28. & 2. & Obraz olejny: Zdjęcie z krzyża \\
\hline 29. & 3. & 4 obrazy przedstawiające 4 pory roku \\
\hline 30. & 4. & Portret cesarza Józefa II \\
\hline 31. & 5. & 18 portretów kanoników lwowskich \\
\hline 32. & 6. & Portret arcybiskupa Ferdynanda Kickiego \\
\hline 33. & 7. & 2 portrety cesarzowej Marii Teresy i cesarza Józefa II \\
\hline 34. & 8. & Portret papieża Piusa VI \\
\hline 35 . & 9. & 40 portretów arcybiskupów ${ }^{\mathrm{ap}}$ \\
\hline 36. & 11. & 2 portrety cesarzowej Marii Teresy i cesarza Józefa II \\
\hline 37. & 12. & Obraz zniszczony \\
\hline 38. & & Obraz: Ukrzyżowanie \\
\hline 39. & & Rycina przedstawiająca św. Józefa ${ }^{66}$ \\
\hline 40. & & 3 duże obrazy przedstawiające wiarę, nadzieję i miłość \\
\hline
\end{tabular}

ao. Na marginesie, przy całej tej grupie, ks. Demitrowski zanotował: "Zniszczone w czasie działań wojennych w r. 1914-1919". Na końcu wykazu umieścił on dodatkowo adnotację na temat niewymienionego w nim obrazu: „Kopię Rafaela «Rodzina św.» zabrał z pałacu jenerał rosyjski Hlasko w r. 1915 w czerwcu".

ap. Na marginesie, przy tej pozycji, ks. Demitrowski napisał: „Przeniesiono do pałacu arcybiskupiego we Lwowie w zimie 1914/15 przy współudziale ówczesnego administratora parafii ob. łac. X. Jan[a] Pawła Steciaka. Z obawy przed rabunkiem ze strony żołnierzy rosyjskich portrety załadowano na wóz ze sianem i jako siano przewieziono do Lwowa po opłaceniu się odpowiednim posterunkom wojskowym. Załatwił to z niemałym sprytem ogrodnik Wiktor Nowotny".

66. Józef Oblubieniec, święty, cieśla, pochodził z rodu Dawida, prawny opiekun Jezusa Chrystusa i mąż Maryi, postać z Ewangelii św. Mateusza i św. Łukasza. Szerszej: S. Szymik, Józef Oblubieniec, w: EK, t. 8, Lublin 2000, kol. 124-125. 
Spis roślin, tudzież sprzętów i narzędzi ogrodowych

\begin{tabular}{|c|c|}
\hline Rośliny oranżeryjne & Sztuk \\
\hline Abutilon w 10 odmianach & 60 \\
\hline Acacia lophantha & 10 \\
\hline Agapanthus umbellatus & 6 \\
\hline Azalea indica & 2 \\
\hline Buxus pyramidalis & 10 \\
\hline Buxus sempervirens & 50 \\
\hline Camellia japonica (słabe) & 5 \\
\hline Correa alba & 20 \\
\hline Cupressus pyramidalis & 10 \\
\hline Cryptomeria japonica & 15 \\
\hline Cytisus (genista umbellata) & 10 \\
\hline Cineraria splendens & 5 \\
\hline Cytryn dużych (2 słabe) & 8 \\
\hline Cytryn małych & 20 \\
\hline Convallaria japonica & 30 \\
\hline Cephalotaxus & 20 \\
\hline Datura arborea starych & 7 \\
\hline Datura arborea młodych & 10 \\
\hline Eucalyptus globulus & 2 \\
\hline Eugenia australis & 15 \\
\hline Eupatorium weinmanni & 10 \\
\hline Euonymus japonica & 150 \\
\hline Euonymus japonica flor[ens] var[iegata] & 100 \\
\hline Euonymus japonica flor[ens] aur[atis] & 10 \\
\hline Euonymus radicans flor[ens] var[iegata] & 80 \\
\hline Elaeagnus angustifolia & 15 \\
\hline Fuxia hybr[id] & 100 \\
\hline Fig dużych & 7 \\
\hline Fig małych & 20 \\
\hline Gynerium argenteum & 2 \\
\hline Habrothaimus speciosa & 30 \\
\hline Hedera helix (bluszcz) & 50 \\
\hline Hortensja & 10 \\
\hline Ilex aquifolium & 5 \\
\hline Jasminum nudiflorum & 5 \\
\hline
\end{tabular}




\begin{tabular}{|c|c|}
\hline Laurus nobilis & 1 \\
\hline Laurus $^{67}$ & 20 \\
\hline Laurus camphora & 1 \\
\hline Libonia floribunda & 50 \\
\hline Melaleuca alba & 10 \\
\hline Melaleuca ericifolia & 15 \\
\hline Myrthus angustifolia & 20 \\
\hline Myrthus comunis & 20 \\
\hline Ophiopogon jaburan & 10 \\
\hline Ophiopogon flor[ens] ord[inarius] & 10 \\
\hline Ophiopogon japonicus & 10 \\
\hline Pittosporum tobira & 5 \\
\hline Pelargonium w gatunkach & 100 \\
\hline Plumbago capensis & 5 \\
\hline Plumbago caerulea & 2 \\
\hline Phormium tenax & 2 \\
\hline Polygala rotundifolia & 5 \\
\hline Punica granatum & 1 \\
\hline Ruellia maculata & 20 \\
\hline Retinosphora crievides & 50 \\
\hline Rhododendron arboreum & 1 \\
\hline Rhus lanceolata & 30 \\
\hline Rhus trifoliata & 30 \\
\hline Salvia officinalis & 5 \\
\hline Salvia splendens & 5 \\
\hline Solanum hendersonii & 20 \\
\hline Sparmannia africana & 5 \\
\hline Thuja occidentalis & 10 \\
\hline Trytoma uvaria & 6 \\
\hline Tecoma jasminoides & 2 \\
\hline Urtica lineusis & 20 \\
\hline Viburnum Tinus & 10 \\
\hline Vinca maior & 5 \\
\hline Vinca maior fol[iis] Var[iegata] & 5 \\
\hline Veronica & 20 \\
\hline Yucca aloifolia & 5 \\
\hline
\end{tabular}

67. Obok widnieją dwa nieczytelne wyrazy w języku łacińskim. 


\begin{tabular}{|c|c|}
\hline Yucca gloriosa & 5 \\
\hline Kaktusów różnego gatunku & 133 \\
\hline Roślin jednorocznych & 562 \\
\hline Roślin bulwiastych i cebulkowych & 500 \\
\hline \multicolumn{2}{|l|}{ Krzewy ozdobne } \\
\hline Amygdalus nana fol[iis] pl[uralis] & 2 \\
\hline Calycantus floridus & 5 \\
\hline Deutzia crenata alba & 10 \\
\hline Lonicera (caprifolium) & 2 \\
\hline Rhus cotinus & 1 \\
\hline Róż szczepionych sztamowych & 100 \\
\hline Róż szczepionych niskich & 20 \\
\hline Róż szczepionych miesięcznych & 25 \\
\hline Thuya orientalis & 1 \\
\hline Weigela & 2 \\
\hline Roślin dywanowych & 710 \\
\hline \multicolumn{2}{|l|}{ Rośliny cieplarniane } \\
\hline Anthurium andreanum & 1 \\
\hline Anthurium scherzerianum & 1 \\
\hline Amaryllis w gatunkach & 100 \\
\hline Aspidistra elatior & 20 \\
\hline Aspidistra elatior fol[iis] Var[iegata] & 20 \\
\hline Asparagus plumosus & 1 \\
\hline Asparagus laevissimus & 10 \\
\hline Arum odoratum & 30 \\
\hline Begonie liściaste (w 10 odm[ianach]) & 100 \\
\hline Begonie bulwiaste & 30 \\
\hline Begonie łodygowe i semperflor[ens] & 50 \\
\hline Boehmeria argentea & 1 \\
\hline Clivia nobilis & 5 \\
\hline Caladium mexicanum & 20 \\
\hline Carex japonica fol[iis] Var[iegata] & 5 \\
\hline Calla aethiopica & 1 \\
\hline Cordyline congesta & 15 \\
\hline Cordyline indivisa & 10 \\
\hline Cordyline rubra & 15 \\
\hline Cordyline vivipara & 10 \\
\hline Curculigo recurvata & 5 \\
\hline
\end{tabular}




\begin{tabular}{|c|c|}
\hline Cyperus alternifolius & 20 \\
\hline Cyclamen persicum & 50 \\
\hline Dracaena draco & 2 \\
\hline Epiphyllum truncatum & 30 \\
\hline Epiphyllum $^{68}$ & 10 \\
\hline Eucharis amazonica & 1 \\
\hline Ficus elastica & 30 \\
\hline Ficus australis & 60 \\
\hline Ficus stipulata & 5 \\
\hline Billbergia amoena & 20 \\
\hline Gloxinia hybr[ida] & 5 \\
\hline Hoya carnosa & 20 \\
\hline Hechtia glomerata & 5 \\
\hline Hedychium gardneri[anum] & 1 \\
\hline Isolepis gracilis & 15 \\
\hline Imatyfollum & 5 \\
\hline Institia rosea & 10 \\
\hline Institia rubra & 50 \\
\hline Maranta zebrina & 2 \\
\hline Maranta Letrei & 2 \\
\hline Mimulus moschatus & 10 \\
\hline Oplismenus imbecillis & 5 \\
\hline Pandanus graminifolius & 1 \\
\hline Pandanus veitschii & 1 \\
\hline Passiflora trifasciata & 10 \\
\hline Pallangum lineare folium & 20 \\
\hline Phrynium sesasum & 50 \\
\hline Pereskia & 20 \\
\hline Philodendron giganteum & 15 \\
\hline Philodendron pertusum & 5 \\
\hline Paperomia argyreia & 1 \\
\hline Sanchezia nobilis & 3 \\
\hline Strobilantes dyerianus & 1 \\
\hline Tradescantia discolor & 10 \\
\hline Tradescantia lineata & 10 \\
\hline
\end{tabular}

68. Obok nazwy rośliny dopisane są trzy nieczytelne wyrazy.

112 Folia Historica Cracoviensia, t. 23, z. 2 (2017) 


\begin{tabular}{lr}
\hline Tradescantia rubra & 10 \\
\hline Urtica macrophylla & 25 \\
\hline Palmy & 3 \\
\hline Latania borbonica & 10 \\
\hline Latania borbonica (młodych) & 20 \\
\hline Phoenix dactylifera & 105 \\
\hline Phoenix reclinata (w pałacu) & 15 \\
\hline Paproci (w 8 gatunkach) & \\
\hline Storczyków (w 6 gatunkach) & \\
\hline Naczynia i sprzęty ogrodowe & \\
\hline 8 kanap siatych i desek & \\
\hline 3 stoły ogrodowe & \\
\hline 58 okien inspektowych starych & \\
\hline 2 skrzynie inspektowe 18 m długie z brusów \\
\hline dębowych
\end{tabular}




\begin{tabular}{|c|c|}
\hline \multicolumn{2}{|l|}{2 młotki } \\
\hline \multicolumn{2}{|l|}{1 sekator } \\
\hline \multicolumn{2}{|l|}{1 świderek } \\
\hline \multicolumn{2}{|l|}{1 dłuto } \\
\hline \multicolumn{2}{|l|}{1 spust do noszenia wody } \\
\hline \multicolumn{2}{|l|}{$1 \mathrm{kosa}$} \\
\hline \multicolumn{2}{|l|}{3 ciepłomierzy [sic] } \\
\hline \multicolumn{2}{|l|}{1 diament do szkła } \\
\hline \multicolumn{2}{|l|}{1 łańcuch żelazny 28 m długi } \\
\hline \multicolumn{2}{|l|}{59 wazonów drewnianych } \\
\hline \multicolumn{2}{|c|}{2500 wazonów glinianych różnej wielkości } \\
\hline \multicolumn{2}{|l|}{ Drzewa i krzewy owocowe } \\
\hline Jabłoni & 396 \\
\hline Gruszy & 70 \\
\hline Śliw & 650 \\
\hline Wiszeń & 400 \\
\hline Czereszeńn $^{69}$ & 11 \\
\hline Renklod & 29 \\
\hline Brzoskwini & 7 \\
\hline Morel & 3 \\
\hline Winogron starych & 43 \\
\hline Winogron młodych & 10 \\
\hline Malin & 1000 \\
\hline Agresta [sic] & 50 \\
\hline Porzeczek & 100 \\
\hline Truskawek & 100 \\
\hline Poziomek miesięcznych & 100 \\
\hline Jabłoni młodych w szkółce & 100 \\
\hline Gruszek & 20 \\
\hline Dziczek jabłoni & 500 \\
\hline Dziczek gruszek & 200 \\
\hline Dziczek śliwek & 100 \\
\hline Drzew w parku tudzież na podwórzu & 1844 \\
\hline
\end{tabular}

69. Styl zgodny z oryginałem. Mowa jest o czereśniach. 
70. Zenon Lubomęski (1838-1914), święcenia kapłańskie w 1863 we Lwowie, wikariusz par. Cieszanów 1863-1864, wikariusz par. Załoźce 1864-1866, wikariusz par. św. Mikołaja we Lwowie 1866-1868, wikariusz par. katedralnej we Lwowie 1869-1871, katecheta Seminarium Nauczycielskiego Męskiego we Lwowie 1871-1880, superior i ojciec duchowny w Małym Seminarium we Lwowie 1873-1874, katecheta Gimnazjum II we Lwowie 1880-1889, spowiednik zwyczajny sióstr Boromeuszek we Lwowie 1884-1889, proboszcz par. Bełz 1889-1895, dziekan dekanatu Bełz 1893-1895, dziekan dekanatu Gródek Jagielloński 1895-1897, spowiednik sióstr Sacre-Coeur 1896-1901, asesor Konsystorza i diecezjalnego sądu małżeńskiego 1897-1914, egzaminator prosynodalny 1897-1914, kanonik gremialny Kapituły Metropolitalnej we Lwowie 1895-1907, kanonik scholastyk Kapituły Metropolitalnej we Lwowie 1907-1912, kanonik kustosz Kapituły Metropolitalnej we Lwowie 1912-1913, dziekan infułat Kapituły Metropolitalnej we Lwowie 1913-1914, dziekan dekanatu Lwów-miasto 1902-1914, proboszcz par. katedralnej we Lwowie 1902-1914, spowiednik sióstr sakramentek oraz karmelitanek 1906, prałat papieski od 1902. Catalogus [Schematismus, Elenchus], 1863-1916, passim.

71. Ignacy Korzeniowski, radca c. k. Namiestnictwa we Lwowie w l. 1899-1905, następnie od 1906 radca dworu w tymże c. k. Namiestnictwie. Szematyzm [...] 1899-19o6, Leopoli 1899-1906, passim. 


\section{Bibliografia}

Źródła archiwalne:

Archiwum Lwowskiej Kurii Metropolitalnej w Krakowie (Archiwum im. abp. Eugeniusza Baziaka w Krakowie przy Uniwersytecie Papieskim Jana Pawła II w Krakowie):

Archiwum Zarządu Dóbr Stołowych, sygn. 135, Inwentarz pałacu rezydencjalnego we Lwowie i dóbr w kluczu obroszyńskim należących do łac. arcybiskupstwa lwowskiego spisany i uzupełniony w roku 1884/5.

Archiwum Zarządu Dóbr Stołowych, sygn. 136, Pałac oraz klucz obroszyński, b. d. [ok. 1900].

S. Morawski, Mój dziennik, t. 19: 1885-1886, passim; t. 22: 1888-1889, passim; t. 26: 1893-1895, passim.

\section{Źródła drukowane:}

Catalogus [Schematismus, Elenchus] universi venerabilis cleri saecularis et regularis archidioecesis Leopoliensis rit. lat., Leopoli 1861-1916.

Inwentarz lwowskiej bazyliki metropolitalnej obrzadku łacińskiego kaplic rezydencji arcybiskupów we Lwowie i Obroszynie XIX/XX wieku oraz jego losy po II wojnie światowej w Polsce, opr. J. Wołczański, Lwów-Kraków 2013.

Szematyzm Królestwa Galicji i Lodomerii z wielkiem księstwem krakowskiem, Lwów 1873-1908.

\section{Opracowania:}

R. Aftanazy, Materiały do dziejów rezydencji, red. A. Baranowski, t. 7a, Dawne województwo ruskie: Ziemia Halicka i Lwowska, Warszawa 1990.

M. Dzieduszycki, Żywot Wacława Hieronima Sierakowskiego arcybiskupa lwowskiego, Kraków 1868. 
Encyklopedia Katolicka, t. 2, Lublin 1985; t. 4, Lublin 1985; t. 7, Lublin 1997;

t. 8, Lublin 2000; t. 11, Lublin 2006; t. 15, Lublin 2011; t. 18, Lublin 2013;

t. 20, Lublin 2014.

Z. Góralski, Maria Teresa, Wrocław 1995.

† Ks. Andrzej Mazurak, "Gazeta Lwowska" 1896 nr 7, s. 3.

† Leopold Szabel, "Gazeta Lwowska" 1897 nr 225, s. 2.

Zmarli, "Słowo Polskie" 1897 nr 231, s. 3. 


\section{Abstract}

Grzegorz Chajko

The Residence of Lviv Archbishops of the Latin Rite Obroszyn

(Obroshyne) near Lviv in the years 1885-1923. A source edition of inventories

Keywords:

Lviv Archdiocese, palace architecture, palace, residence, Lviv, Obroszyn, Obroshyne.
This article presents two inventories of the Lviv Archbishop of the Latin Rite in Obroszyn in the form of a source edition. They were analysed and labelled with back matter. Their content includes information about the design and organization of the entire palace/park establishment, as well as external appearance, floor plan and furnishings of the palace. In addition, they contain extensive lists of exotic plants grown in the orangery. It is also worth noting that the documents in this publication fill a significant gap in the history of the palace in Obroszyn. Never before have these inventories been published. 


\section{Abstrakt}

Grzegorz Chajko

Pałac arcybiskupów lwowskich obrządku łacińskiego w Obroszynie

koło Lwowa w latach 1885-1923. Edycja źródłowa inwentarzy

W niniejszym artykule zostały zaprezentowane w formie edycji źródłowej dwa inwentarze pałacu arcybiskupów lwowskich obrządku łacińskiego w Obroszynie. Poddano je analizie i opatrzono aparatem naukowym. W swojej treści zawierają one informacje na temat wyglądu i organizacji całego założenia pałacowo-parkowego, a także wyglądu zewnętrznego, układu pomieszczeń oraz wyposażenia budynku pałacowego. Dodatkowo zawarte są w nich obszerne wykazy egzotycznych roślin hodowanych w oranżerii. Warto też zaznaczyć, że publikowane dokumenty wypełniaja istotną lukę w historii pałacu w Obroszynie. Inwentarze te nie były wcześniej publikowane.

Słowa kluczowe: Archidiecezja lwowska, architektura pałacowa, pałac, Lwów, Obroszyn. 
